\title{
Borrowing Culture and Debt Relief: \\ Evidence from a Policy Experiment
}

\author{
Sankar De $\mathrm{a}^{\mathrm{a}}$ \\ Prasanna Tantri ${ }^{\text {b }}$
}

April 2013

Present version: September, 2013

\begin{abstract}
Using a model as well as extensive empirical tests, the present paper investigates the effects of a large-scale debt relief program on the post-waiver debt repayment behavior of borrowers in a rural credit market where the farmers borrow from banks at a subsidized rate and from informal sources at a substantially higher rate, debt contract enforcement is imperfect, and political interventions in the credit market in the form of debt relief can happen even in normal states of the economy. Our model includes all classes of borrowers: those who receive full debt relief, those who receive partial debt relief, and those who do not benefit at all from the program as they do not have overdue loans. The effects are negative for all groups. Following a debt relief program, the number of days taken to repay debt increases for all borrowers who behave strategically, causing ex post inefficiency in the credit market. Interestingly, the effects are the most negative for the group that do not benefit at all. Expectations about similar debt relief in future coupled with extensions on loan repayment granted by bankers who find debt recovery difficult drive our results. Further, rationally anticipating adverse borrower behavior, the lending institutions ration credit, generating ex ante inefficiency as well. Ironically, access to finance for poor households declines following unconditional debt relief. We confirm the predictions of the model with extensive tests using loan accounts data for a large sample of rural borrowers before and after a nation-wide debt relief program undertaken by the Indian government in 2008 , one of the largest such programs in history.

Keywords: bank credit; borrowing culture; debt relief; credit market interventions. JEL Classifications: G21, O2, Q14

${ }^{\text {a }}$ Shiv Nadar University, UP, INDIA

${ }^{b}$ Centre for Analytical Finance (CAF), Indian School of Business (ISB), Hyderabad, INDIA.

Sankar De (corresponding author) can be reached at drsankarde@gmail.com . The authors thank an Indian public sector bank for the data used in this paper. They also thank Bhimasankaran Pochiraju for econometric help and guidance, and Raghuram Rajan for encouragement at an earlier stage of the project. Chitrath Kaushik, B. Padmapriya, Mohan Ramnath, and Arkodipta Sarkar provided valuable research assistance at different stages of the project. The authors remain responsible for all errors.
\end{abstract}




\section{Introduction}

The current state of knowledge about the economic consequences of a large-scale debt relief program is inconclusive. Several existing economic models suggest that in certain situations debt relief generates investment and productivity gains for the borrowers and economic efficiency gains for the credit markets. Large-scale debt relief reduces debt overhang problems and risk-shifting incentives of heavily indebted borrowers (Jensen and Meckling 1976, Myers 1977) and lifts poor borrowers out of their 'poverty traps' and low-productivity equilibria (Banerjee and Newman 1993, Banerjee 2000, Mookherjee and Ray 2003). State-contingent debt moratoria, imposed on creditors in an adverse state of the economy, may result in ex ante as well as ex post efficiency gains (Bolton and Rosenthal, 2002).

However, unconditional debt waivers may impair the culture of prudent borrowing. Borrowers may strategically respond to a debt waiver by borrowing and investing heavily, expecting to be bailed out again. In an unintended, and very unfortunate, consequence of debt relief, the lending institutions, rationally anticipating an adverse change in borrower behavior, may ration credit, especially if debt contract enforcement is not perfect and loan recovery is uncertain as is the case in many emerging economies. Besides, economic costs of government intervention in debt markets can be huge (La Porta, Lopez De-Silanes, and Shleifer (2002), Cole (2009), Dinc (2005), Khwaja and Mian (2005)).

Following the global financial crisis of 2008, many sizable debt relief programs have taken place across the globe in recent years. However, we find no study in the existing literature that either models the effects of a debt relief program on the post-waiver loan repayment behavior of strategic borrowers who factor in the probability of another waiver in their repayment decisions ${ }^{1}$, or empirically documents the effects. Lack of reliable loan accounts data for retail borrowers has been a hindrance to empirical investigations. The present paper attempts to fill in the gaps in the existing literature. Using a model as well as extensive empirical tests, we investigate the effects of a large-scale debt relief program on the postwaiver debt repayment behavior of borrowers in a realistic setting. We consider a rural credit

\footnotetext{
${ }^{1}$ The seminal papers by Alston (1984) and Bolton and Rosenthal (2002) on government interventions do not model strategic behavior by borrowers. Please see our discussion in section II of this paper.
} 
market typical of many emerging economies where the farmers borrow from banks at a government-mandated subsidized rate and from informal sources at a substantially higher rate, debt contract enforcement is imperfect, and political interventions in the credit market in the form of debt relief for overdue loans can happen even in normal states of the economy. We also consider a more comprehensive setting than the existing studies of political interventions in private debt contracts. We investigate the effects of a loan waiver program not only the on the borrowing behavior of the farmers but also the on the lending strategies of the creditors and, again, among the borrowers not only on those who actually benefit from the program and have their debt written off but also those who are excluded. To the best of our knowledge, it is also the first study that uses actual loan account level data to conduct the investigations. In the next section of the paper, we discuss the scope of the present paper in the context of the existing literature.

The paper presents a simple but realistic model of debt repayment behavior of strategic borrowers following a sizable debt relief program, and empirically tests the predictions of the model. The model offers clear and testable predictions of adverse changes in borrower behavior. In our empirical work, which is the major focus of the present paper, we extensively test the predictions of the model. We investigate the effects of a truly large debt waiver program on the recorded debt repayment patterns of a large sample of borrowers and lending practices of the creditors. Officially christened the Debt Relief and Debt Waiver Scheme for Small and Marginal Farmers, the program was announced by the Indian finance minister on February 29, 2008, as part of the annual budget for 2008 - 09. It was one of the largest debt relief programs in history. The program ultimately covered a total of 716.8 billion Indian rupees (INR) outstanding farm debt owed to commercial banks and an estimated 36 million farmers. The cost of the program was USD 15.9 billion at the prevailing rate of exchange and amounted to $1.3 \%$ of the country's GDP. As the finance minister himself acknowledged, "in terms of scope, coverage and the financial cost, this was the most ambitious scheme ever undertaken by any Government in India." ${ }^{2}$ The waiver program constituted a massive transfer from the exchequer

\footnotetext{
${ }^{2}$ Farmers' Debt Waiver Scheme - Text of the FM's Statement, May 23, 2008, issued by the Press Information Bureau, Government of India.
} 
to the farmers. The banks that wrote off the loans were reimbursed in full by the government. Another interesting aspect of the program was that it was totally unanticipated. It was the first, and so far the only, nation-wide agricultural debt relief program in India. Though it had been recognized in policy circles for some time that rural indebtedness was a serious problem in India, the years preceding the program experienced normal annual rainfall and increasing foodgrains production. In fact, 2007 was a particularly good year in terms of rainfall and agricultural production ${ }^{3}$. There had been no discussions in the press or in other public forums that anticipated the program. In fact, a government-appointed committee (Radhakrishna Committee, 2007)) charged with the task of making recommendations to reduce rural indebtedness in India had not recommended debt waiver ${ }^{4}$. The next section of the paper describes the key features of the program.

In our model, presented in section IV below, a large-scale debt waiver program which is not state-contingent creates expectations of similar debt relief initiatives in future, The farmers strategically decide whether to repay or default on their current debt in anticipation of another debt waiver, and the bankers, who wish to avoid a default because it affects their records, decide whether to grant the farmers an extension for a length of time after their debt becomes due. The farmers weigh the benefit of a future debt waiver against the opportunity cost of defaulting on their current loans and being denied bank credit in future and, in case no debt waiver materializes, having to opt for financing at a much higher cost from the informal sector. The conflict between the two outcomes is affected by their type (good or bad), which determines their opportunity cost of losing bank credit, and credit history which determines the length of the extension (grace period) granted by the bankers on their current loans. The group of borrowers who did not have any overdue debt when the last debt relief program was announced enjoys the longest extension, thanks to their good credit records. They use it to take longer than the other borrowers to pay off their debt in the post-waiver period. The model predicts a pervasive deterioration of loan repayment culture and ex-post inefficiency in the

\footnotetext{
${ }^{3}$ See our discussion in section III and supporting data in the appendix at the end of this paper.

${ }^{4}$ In his budget speech the finance minister himself noted that the committee had stopped short of recommending agricultural loan waiver.
} 
credit market induced by the debt waiver program, with the borrowers with no default on their records displaying worse behavior ex-post than the past defaulters.

How do the bank loan officers respond to new loan applications in the wake of a debt waiver program? We consider their response ex-ante as well as ex-post. In our model, the bankers' response ex ante to new loan applications in the post-waiver period as well as ex-post to loans already approved incorporates a couple of ground-level realities of the Indian credit market which have been widely noted in the existing literature. A well performing loan adds to the loan officer's performance records, and a bad loan affects them negatively. However, the magnitude of punishment for a bad loan is far higher than the reward for good performance, especially in Indian public sector banks (see Banerjee and Duflo, 2008). Without loss of generality, we assume no reward for good performance, and a punishment for a bad loan ${ }^{5}$. In this situation, the loan officers, rationally anticipating an adverse change in borrower behavior in the post-waiver period, will decrease lending ex-ante. It is a good strategy for them to reject new loan applications from their existing clients which, in their judgment, have a high probability of defaulting, and resort to credit rationing. Further, the probability of a loan application rejection is significantly higher for the farmers who had defaulted in the past compared to those who did not. The former are more likely to be inferior farmers who present a higher risk of defaulting again in future than the other farmers. Even if they are able to pay off the new loans they are more likely to take longer to do so since their opportunity cost of foregoing a bank loan is lower. For the small and marginal farmers the ultimate consequence of debt relief is a decline in access to credit, exactly the opposite of what debt relief programs are intended to deliver.

In our model, it is the same motivation to avoid a non-performing loan that makes the bankers adopt a more forbearing stance with the new loans already approved. To avoid a default on their records, they grant an extension ex-post to the maturity period of a loan in keeping with the credit history of the borrower. In other words, their strategies generate both ex ante and ex post inefficiencies in the rural credit market. This would not be the case if the loan contracts were enforceable and bad debt rare. However, the reality in the rural economy

\footnotetext{
${ }^{5}$ Banerjee and Duflo, 2008, make a similar assumption.
} 
of India, and most other emerging economies, is quite different. Though agricultural credit is typically collateralized by the landholdings of the farmers, possession of the borrower's land in case of a default is practically infeasible. Commercial legal system in India and many other emerging countries is notoriously ineffective $e^{6}$. But, more importantly, seizure of farmers' land by creditors is politically unacceptable for most state governments who discourage it. Since agricultural loans in India are covered by priority sector norms enjoining a fixed (and subsidized) rate of interest, the banks are also prevented from charging higher rates on overdue loans.

Expectations of similar debt relief programs in future coupled with extensions granted by the bankers on the current loans drive the ex post borrower behavior results in our model. On the other hand, anticipation of adverse borrower behavior ex post generates the result that the bank credit officers ration credit ex ante Our empirical investigations confirm the predictions of the model. We use loan account level data for a large sample of rural borrowers for several years before and after the 2008 loan waiver program. The scope of our investigations is comprehensive. We compare the effects of the program on the debt repayment culture of different groups of borrowers: small and marginal farmers ${ }^{7}$ who had overdue debt and received full debt relief, bigger farmers who had overdue debt and received partial debt relief, and a third group comprising both types of farmers who did not benefit at all from the program as their loans were not in default. We find that the effects on debt repayment behavior are negative for all groups. The number of days taken to repay debt appears to increase for all borrowers in the post-waiver period. However, in consistence with the model's prediction, the effects are the most negative for the group that had not defaulted and, as a result, did not benefit at all from the program. In their case the loan repayment time worsens not only absolutely compared to the pre-waiver period but also relatively to the other groups. The results are robust to alternative specifications and all reasonable controls. In fact, the difference in the size of landholdings, loans, or outputs between the pre-waiver and post-

\footnotetext{
${ }^{6}$ See, for example, Allen, Qian, and Qian (2005), and Allen, Chakrabarti, De, Qian and Qian (2012) on costly financial implications of weak contract enforcements in China and India respectively.

${ }^{7}$ The Reserve Bank of India (RBI) defines small and marginal farmers as farmers with less than 2 hectares of landholding.
} 
waiver periods for a given farmer appears not to explain at all the difference in the farmers' loan repayment behavior in the two periods. Though landholding, loan volume, and output quantity are normally important variables in a farmer's payment decisions, they remain fairly static over a length of time for a typical farmer in rural India. Hence, the difference in the values of the variables between two consecutive time-periods is usually not significant. As predicted in the model, the lending institutions cut off funding to some of their past borrowers. The probability of new loan rejection is significantly higher for the past defaulters than for those who had not defaulted.

Our data and setting are particularly suitable for the goals of this paper. Our sample consists of panel data of complete transaction records for about sixteen thousand agricultural loan accounts over a long period (October 2005 - May 2012). The accounts are spread over four districts in the state of Andhra Pradesh in India. The transactions records for the accounts include not only the details of each transaction but also a sufficiently detailed description of the exact nature of the transaction. With the help of the description and other variables, we are able to determine when a particular loan was taken, the amount of the loan, the interest and other charges like maintenance charge, legal notice charge etc., and when the loan was repaid and how long the payment period was. Section IV below of this paper presents a fuller description of the data.

The announcement of the debt waiver program (February 2008) was right in the middle of the sample period which gives us a sufficiently long period before as well as after the program to observe and compare the borrowing behavior of the farmers in our sample. For several of our empirical tests we use a difference-in-difference framework where, depending on the test specification, the borrowers who received full or partial waiver serve as the "treatment" group and those who received no waiver serve as the "control" group. The framework enables us to conduct clean tests of the causal impact of the debt waiver on the borrowing behavior of the farmers in our sample. The panel-setting allows the inclusion of bank branch fixed-effects in our regression models which rules out spurious correlations due to time-invariant branch characteristics. We also control for land holdings of the farmers in our 
sample wherever available, agricultural production at the district level, and inflation for agricultural laborers (CPIAL) released by the government of India.

Let us note that deterioration in agricultural loan repayment in the post-waiver period was by no means a unique experience of the public sector bank that gave us the loan account level data. Nationwide data from the period suggests that the deterioration was pervasive. Graph 1 below plots agricultural loans of all public sector banks turning into NPAs against agricultural production in India during the period. Though agricultural production steadily improved over the period, agricultural NPAs first declined sharply during 2008-9 as a result of the massive overdue debt waiver scheme but then shot up. The massive increase in agricultural NPAs in the post-waiver period does not indicate a general decline in the efficiency of the banks to recover overdue loans. Graph 2 below compares agricultural NPAs and total NPAs of the banks in the same period. Though total NPAs increased over the post-waiver period as it coincided with the financial crisis and its aftermath, the increase in agricultural NPAs was noticeably more pronounced.

\section{Graphs 1 and 2 here}

Before proceeding further, we would like to clarify that our results do not suggest that all government interventions in private debt markets have negative consequences. There are situations where agricultural debt relief is necessary and improves efficiency, such as debt relief following a severe drought. As we have stated above, and as will demonstrate below, anticipation of more debt relief programs in future coupled with extensions on debt repayment beyond the due date permitted by the bankers drive our results. If the two contributory factors are controlled appropriately, adverse efficiency implications of a debt relief program will be minimized. However, controlling them is no mean task. It will require political discipline backed by a clearly articulated policy of interventions only in poor states of nature which will limit undue expectations. It will also require tricter enforcement of debt contracts, enabling bank loan officers to handle prospects of bad debt with more confidence and less risk to their performance records. In other words, the task will require substantial political and structural reform. 
The paper proceeds in the following manner. Section II positions our paper in the context of the existing literature. Section III describes the 2008 debt relief program. Section IV presents our model and its predictions. Section $V$ describes the data used to test the predictions. Section VI presents our empirical methodology. Section VII presents the results regarding the borrowing behavior of the farmers in the pre and post-waiver periods. Section VIII examines some alternative explanations for our results. Section IX presents our results concerning the response of the lending institutions to the program in terms of its lending strategies in the post-waiver period. Section X presents our conclusions.

\section{The existing literature and our motivation}

In an important study on economic implications of political interventions in credit markets, Bolton and Rosenthal (2002) consider an agrarian economy where poor farmers borrow from rich farmers, debt contracts are perfectly enforceable, and political interventions in credit markets are not driven by opportunistic motives. Their setting provides an appropriate background for studying debt moratoria imposed on the creditors in the USA during the great depression which is their period of interest. In this setting state-contingent debt moratoria enhance ex post efficiency of the economy if bad economic shocks are highly likely. The efficiency gain is caused by the fact that the inferior farmers who would have been driven out of farming due to foreclosure get a second chance to cultivate. To that extent there is an increase in production. Even the lenders are not worse off as the loans were not recoverable in the first place. However such interventions may reduce ex ante efficiency if the lenders perceive a high chance of intervention. As shown by Alston (1984), there may be widespread credit rationing in this situation. To eliminate this problem, Bolton and Rosenthal (2002) consider a political system where intervention is politically feasible only following an adverse shock. If the creditors expect that the adverse state of nature is sufficiently unlikely and the intervention would happen only in an adverse state, then state-contingent debt moratoria also improve ex ante efficiency by completing debt contracts which are typically incomplete. In their setting, expectations of the borrowers about the next waiver do not play a role since waivers are known to be state-contingent. 
However, the setting in the present paper is markedly different in several important respects, reflecting different objectives of our study. Our goal is to study borrower behavior in addition to creditor behavior in a setting more appropriate for emerging economies. We consider a rural credit market where the farmers borrow from banks at a subsidized rate and from informal sources at a substantially higher rate, and debt contract enforcement is imperfect. In particular our setting allows for populist political interventions in the form of debt relief programs even in a normal state. The political economy literature offers enough compelling evidence that opportunist politicians manage policy with the intention of securing electoral gains ${ }^{8}$. The waiver program that we consider for our empirical investigations involved transfers from the taxpayers to the borrowers, and not from the lenders to the borrowers. The commercial banks who wrote off the loans under the program were fully compensated by the government. This removes a strong opposition group to the waiver as the tax payers do not bear the costs immediately. They are also typically dispersed and do not vote as a bloc ${ }^{9}$. The situation makes opportunistic interventions feasible.

Second, unconditional waivers provide incentives to the borrowers to default strategically in anticipation of further waivers, resulting in ex post inefficiency in our setting. The anticipated adverse behavior on the part of the borrowers, coupled with weak debt contract enforcement typical of most emerging economies, motivates creditors to impose credit rationing, inducing ex ante inefficiency as well. However, we also show that, besides expectations about future debt waivers generated by an unconditional waiver, typical incentive structure for bank loan officers which encourages them not to accept a bad loan on their records and, to that end, grant extensions on debt repayments beyond the due date also contributes to the ex post inefficiency. Poor contract enforcement typical of many emerging economies makes recovery of collaterals difficult (see Allen, Qian, and Qian, 2005, and Allen, Chakrabarti, De, Qian and Qian, 2012, for empirical evidence of poor contract enforcement in

\footnotetext{
${ }^{8}$ The literature on economic costs of politically motivated public policy decisions is extensive and growing. In the specific context of India, in two parallel papers Cole (2009a) and Cole, Healy and Werker (2012) document political capture of public institutions in India, including commercial banking and public distribution systems, resulting in significant differences in provision of agricultural credit and government relief spending at the district level between election and non-election years.

${ }^{9}$ In Bolton and Rosenthal (2002) the creditors and the better borrowers resist waivers in good states.
} 
China and India respectively). The situation compels bankers to give leeway to the errant borrowers. This feature adds an innovative but realistic element to our framework.

Another important difference between our paper and Bolton and Rosenthal (2002) and all other studies in the existing literature is that we consider the behavior of all classes of borrowers following a debt waiver program for overdue loans, including those farmers who do not have overdue debt and are not covered by the program. Their debt repayment records post-waiver worsen the most as their good credit history secures them the most favorable treatment by the bankers. A final critical difference between the scope of our study and that of the others is that we empirically verify the predictions of our model. We extensively test the effects of one of the largest debt relief programs in history on the recorded debt repayment behavior of the borrowers and credit decisions of the lenders in the post-waiver period. In fact, the empirical work is the major focus of the present study.

The existing economic literature suggests two channels through which debt relief may improve investment and productivity at the household level. First, theories of debt overhang and risk-shifting (Jensen and Meckling 1976, Myers 1977) argue that indebtedness affects both the level and risk-profile of investments. Heavily indebted borrowers may forego economically sound investments because the proceeds would largely go toward debt servicing, or may undertake excessively risky investments since much of the downside-risk is borne by the creditors. Second, 'poverty trap' models (Banerjee and Newman 1993, Banerjee 2000, Mookherjee and Ray 2003) argue that household income net of debt service may not be sufficient to cover investments in human or physical capital, causing indebted households to remain in a low-productivity equilibrium. Large-scale debt relief may improve investment and productivity through both channels. Kanz (2011) investigates the effect of the 2008 debt relief program in India on the investment and productivity of about three thousand households that received debt relief in the state of Gujarat. Using data based on a survey of the households, the paper finds no improvement in investment and productivity of the beneficiary households. The focus of the present paper, namely the debt repayment patterns of the farmers and credit decisions of the lending institutions in the post-waiver period compared to the pre-waiver 
period, is very different from the issue of investment and productivity implications of debt waivers.

Our focus is also very different from a recent literature that has developed in the wake of the mortgage crisis in the USA. The central issue in this literature is strategic default decisions when the value of the outstanding loan significantly exceeds the value of the asset financed with the loan (see, for example, Guiso, Sapienza, and Zingales, 2013). By contrast, strategic loan repayment decisions following large-scale debt relief is our subject of interest.

Though scientific research on the cost/benefit implications of the debt waiver program of 2008 has been quite limited so far, we note that there has been much debate and many discussions in the popular press, public forums, and other gatherings on the merits of the program. Given the size and reach of the program, not to mention its proximity to the national elections of 2009, extensive and sometimes heated discussions were inevitable at the time ${ }^{10}$. Interestingly, animated commentary in the press continues even today, five years after the program. A headline in a recent issue of a leading national financial newspaper screams "The farm loan waiver continues to destroy the credit culture in rural India" (Mint, March 15, 2013). As often happens with sweeping public policy initiatives of the kind, the press takes the lead and academic research follows. The present paper is no exception.

\section{Debt Relief Program for Small and Marginal Farmers (2008) In India}

Widespread indebtedness in the rural sector of the Indian economy had long been recognized as a serious problem. Unpredictable rainfall, small landholdings, and high interest rates on loans from private money lenders have been cited as some of the reasons that had pushed rural farmers into unsustainable levels of debt. While the rest of the Indian economy was growing at an average annual rate of $11 \%$ in the early years of the present century, agricultural sector, by far the largest employer of the working age population in the country, grew at an anemic $2.3 \%$ rate. To limit the magnitude of the farm debt problem, from time to time the Indian government had attempted various measures, the most important of them priority sector farm loans at a subsidized rate, and also set up committees to suggest measures.

\footnotetext{
${ }^{10}$ See, for example, Asia Times (March 11, 2008) "15 billion loan waiver reaps harvests of anger".
} 
The last such committee before the agricultural debt waiver program of 2008 was the Expert Committee on Rural Indebtedness, chaired by R. Radhakrishna of the Indira Gandhi Institute for Development Research, Mumbai. The committee's mandate was sweeping: "to look into the problems of agricultural indebtedness in its totality and to suggest measures to provide relief to farmers across the country". The committee submitted its report in July 2007. Two important recommendations of the committee were a government fund specifically set up to provide long-term bank loans to farmers, in an effort to limit high-interest loans from private moneylenders, and special relief packages for a total 100 districts that have been identified as low land productivity areas. Notably, the committee did not recommend any kind of bank loan waiver scheme.

The loan relief program of 2008 was justified in part by the situation created by an increasing number of farmer suicides, most notably in the Vidarbha region of Maharashtra. High indebtedness among farmers was often cited as the reason for the suicides. A combination of other factors, political as well economic, provided additional motivation. Economic arguments that a reduction in household debt would increase the level and efficiency of agricultural investment played a role. Because commercial and cooperative banks that were holding overdue debt were refinanced, the program was also popular with the lending institutions, and may have helped to revive financially troubled institutions. On the other hand, concerns were expressed over the program's impact on subsequent repayment incentives of the beneficiaries ${ }^{11}$. It was also noted that the program constituted a sizable transfer to India's agricultural sector, a very important sector of the economy by share of GDP (19\%) and total employment $(66 \%)$, ahead of national elections ${ }^{12}$. A feature of the program which was heavily criticized is that it covered only formal sources of credit, and excluded all informal loans. Thus, while it benefited relatively big farmers who had access to institutional credit (about $23 \%$ of the

\footnotetext{
${ }^{11}$ See, for example, Kasbekar, Mehak. "Does loan waiver harm credit culture?" Mint, June 2, 2008

${ }^{12}$ According to Parshuram Ray, Director of the New Delhi-based Center for Environment and Food Security, the loan waiver was "an electoral sop that involves a lot of statistical jugglery and very little of real hope for Indian farmers"
} 
total number of farmers), small and marginal farmers, who mostly borrow from private moneylenders in the informal sectors, were not touched by the scheme. ${ }^{13}$

It should be noted that farmers' indebtedness in India is an old problem, almost as old as Indian agriculture itself, though the problem was increasing in magnitude with time. Curiously, the debt relief program of 2008 was launched in a normal state of the rural economy. The years immediately preceding the program experienced normal rainfall and, in fact, increasing agricultural productivity and increasing foodgrains production. In particular, 2007 was a better than normal year in terms of those indicators. We present supporting data in the appendix at the end of this paper. The fact that the program was launched in a normal state of the economy has an important implication for our analysis.

The program covered formal agricultural debt issued by commercial and cooperative banks. The types of debt included crop loans, investment loans for direct agricultural purposes or purposes allied to agriculture, and agricultural debt restructured under prior debt restructuring programs. Over a period of time the government compensated the banks in full for the loans written off under the program. Loans from moneylenders and other informal sources, and loans taken for non-agricultural purposes, were not included in the program.

To qualify for debt relief, a loan had to be overdue or restructured as of December 31, 2007 (well prior to the program announcement on February 29, 2008). The amount of relief depended on the type of loans as well as location and classification of the borrowers. In the case of direct agricultural loans, "small and marginal farmers", defined for the purpose of the program as farmers with landholdings of 2 hectares or less, were eligible for a full $(100 \%)$ waiver, while the "other farmers", defined as those with more than 2 hectares, qualified for partial (25\%) loan relief conditional on repayment of the remaining $75 \%$. In drought-prone and other designated districts, the partial relief was $25 \%$ or INR 20,000 (USD 442), whichever was greater. For allied-to-agriculture loans, farmers with loans INR 50,000 (USD 1,105) and under were considered small or marginal, while farmers with larger loans were considered other farmers. The implementation of the program began on June 30, 2008, with full waivers being

\footnotetext{
${ }^{13}$ Srinivasan, N. "Farm Loan Waiver: Right Choice for Supporting Agriculture?". CAB Calling. College of Agricultural Banking, April-June 2008.
} 
granted immediately. $25 \%$ relief was granted upon repayment of the remaining $75 \%$ within a year. This deadline was eventually extended by one more year in order to accommodate those who faced difficulty repaying their $75 \%$. The goal was $100 \%$ participation.

\section{A simple model and empirical implications}

In this section, we describe a model in which the farmers decide whether to repay or default on their current debt in anticipation of a debt waiver, and the bankers decide whether to grant the farmers an extension after their debt becomes due. The farmers face on the one hand the risk of being denied new loans in case they default, and on the other hand an opportunity to have their debt written off by a government-initiated debt waiver program if they can manage to wait long enough. The conflict between the two outcomes, which are affected by their type and credit history, influences their decision.

\section{A. Setting}

The farmers in the economy come in two types: type 1 (good) and type 2 (bad). The proportions of the two types of farmers in the population of farmers are $\pi$ and $1-\pi$ respectively. Type 1 farmers produce $\Theta$ units of output with a probability of $p_{1}$ and 0 units with a probability of $1-p_{1}$. Type 2 farmers produce $\Theta$ units of output with a probability of $p_{2}$ and 0 units with a probability of 1- $p_{2}$. Let $p_{1}>p_{2}$. The farmers know their own type at time 1 .

There is only one bank that lends to all framers at a uniform and subsidized (priority sector) interest rate $r_{b}$. All loans carry a face value of 1 . The amount to be repaid one period later is denoted as $R$, where $R=1+r_{b}$.

Though agricultural credit in the rural economy of India is typically collateralized by the landholdings of the farmers, possession of the borrower's land in case of a default is mostly not a feasible option for the banks. Since agricultural loans in India are covered by priority sector norms enjoining a fixed (and subsidized) rate of interest, the banks are also prevented from charging higher rates on overdue loans. Barring defaulters from future financing is usually the only disciplining device the banks possess. The model incorporates this realistic feature of the Indian rural credit market. The farmers who are denied bank credit may seek financing at a 
higher rate of interest $r_{m}$ from the informal sector where $r_{m}>r_{b}$. For the sake of notational simplicity we assume that $r_{m}$ is uniform for all farmers. In other words, the market does not know the type of the individual farmers, and credible signals do not exist. All our results will go through if $r_{m 2}>r_{m 1}>r_{b}$, that is the moneylenders know the types, and charge type 2 farmers a higher rate.

\section{B. Bankers' decisions}

The loan officer does not know the type of individual farmers, though she knows the proportions of the two types of farmers: $\pi$ and 1- $\pi$. She also knows their credit history, including whether a given farmer had defaulted on outstanding debt at $t=0$, with the debt being waived off through a government debt waiver program. Though she is required to offer the same priority sector rate $r_{b}$ to all farmers, she can use the farmers' credit history to make other terms different for different farmers.

A well performing loan adds to the loan officer's performance records, and a bad loan affects them negatively. The magnitude of punishment for a bad loan is higher than the reward for good performance. Without loss of generality, we assume no reward for good performance, and a punishment for a bad loan ${ }^{14}$. Hence the loan officer would like the farmers not to default. Note that the incentives of the farmers and the loan officer are in conflict. As long as the probability of a debt waiver is non-zero, the farmer will consider defaulting. However, a default triggers a penalty for the loan officer that she would like to avoid. Therefore, it is a good strategy for the loan officer not to officially accept a bad loan and grant an extension to the credit period. However, the extension cannot be indefinite. A farmer, who was a defaulter at $t=0$ (just before the waiver) gets a grace period of $Y$ days from the due date before the loan officer recognizes the loan as a bad loan and cuts off all future funding to the farmer. The farmers who were not defaulters at $t=0$, get a longer grace period of $X$ days before being cut off from funding where $X>Y$. The absolute values of $x$ and $y$ are not important to our analysis; what matters is that $X>y$. Every day of delay after the due date diminishes the chance of

\footnotetext{
${ }^{14}$ (Banerjee and Duflo, 2008) make a similar assumption.
} 
getting a new bank loan by $1 / Y$ in case of erstwhile defaulters and $1 / x$ in case of non defaulters. Obviously, $1 / Y>1 / X$.

The posterior probability that a defaulter is a type 2 farmer is $(1-\pi)\left(1-p_{2}\right) /(1-\pi)\left(1-p_{2}\right)+\pi\left(1-p_{1}\right)>(1-\pi)$. In other words, the probability that the defaulter is a type 2 farmer is greater than the proportion of type 2 farmers in the population. Therefore the loan officer views a farmer that had defaulted at $t=0$ as more likely to be a type 2 firm than a type 1 firm. It is known that a type 2 firm is more likely to produce zero units and be forced to default. Hence the loan officer regards a farmer that had defaulted at $t=0$ as a likely candidate to default again, and gives him a shorter grace period.

\section{Farmers' decisions}

The farmer has to chose between either paying the loan on or before the due date or default. We assume that the waiver decision is made after the due date. Hence, the farmer's pay-off depends on his production ( $\Theta$ or zero), his action (repay or default) and the state (waiver or no waiver). In case the farmer produces $\Theta$ and decides to repay the loan, he continues to receive funding by the bank. In such a scenario the expected value today of all future production for a farmer of type $i$ is $\Theta^{*} p_{i} / r_{b}$, denoted by $V_{b i}$, where $i=1,2$. In case the farmer defaults in anticipation of a debt waiver, and the waiver indeed happens, the present value of his future production is $V_{b i}+R$. Since the waiver wipes off his debt, making him creditworthy again, he continues to get bank funding in this case. However, if no waiver ensues, there are two possibilities. If his production is $\Theta$, he pays off his loan and continues to receive bank funding. On the other hand, if the value of his production is zero at $t=1$, he is in the worst of both worlds and is denied credit by the bank. In such a case he has to borrow at a higher cost $r_{m}$, where $r_{m}>r_{b}$. The present value of production for the farmers in this case is $\Theta^{*} p_{i} / r_{m}=V_{m i}$. Clearly, $\mathrm{V}_{\mathrm{bi}}>\mathrm{V}_{\mathrm{mi}}$.

The following flow chart presents the decision making of a farmer at $t=1$. 


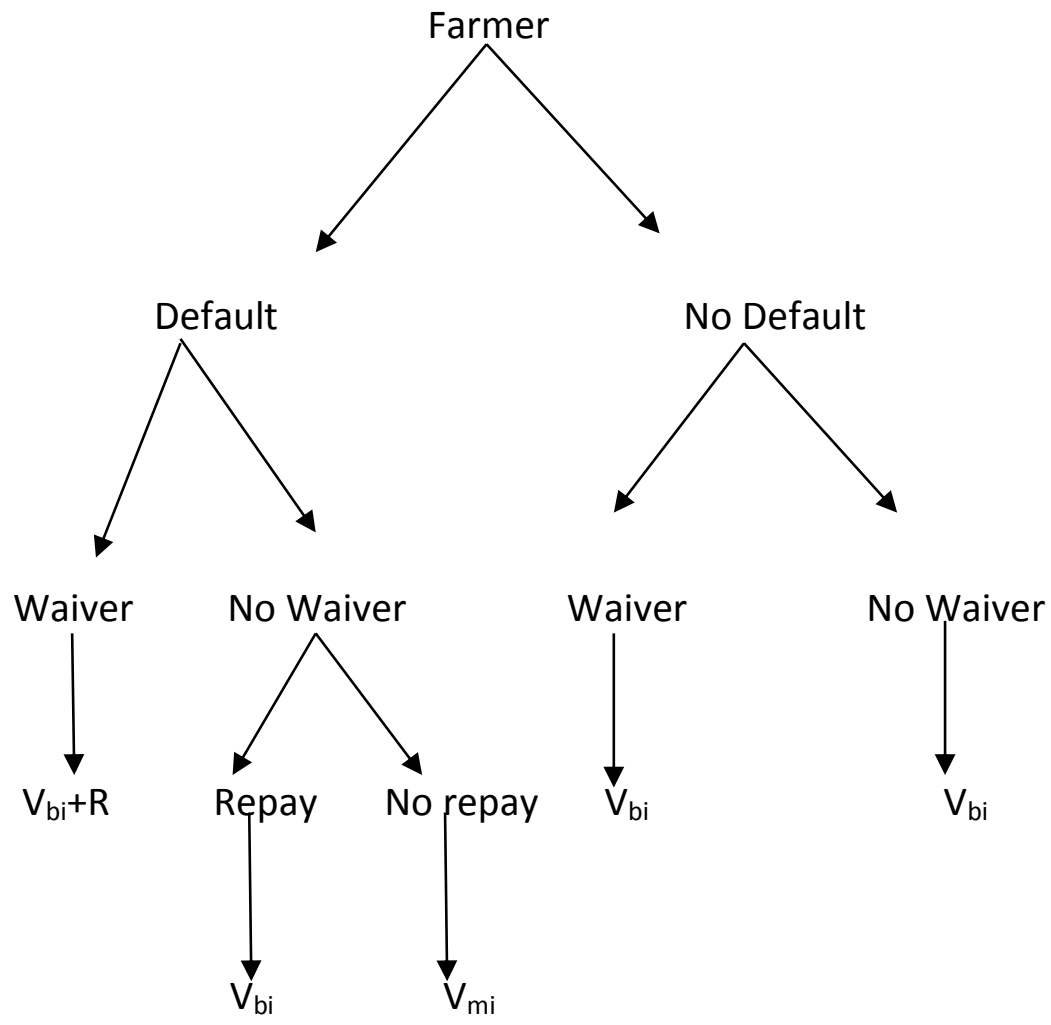

As long as the probability of a debt waiver is non-zero, a farmer will like to weigh the benefit of a debt waiver against the cost of defaulting and being denied bank credit in future. Let $D$ be the number of days since loan becomes due and $P$ the probability of the loan waiver. The optimal number of days a farmer waits after the due date depends on two factors: the farmer's type (1 or 2) and his credit history, specifically if he had defaulted on the previous loan or not which determines the extension ( $\mathrm{X}$ or $\mathrm{Y}$ days) the bank allows. So there are four possible situations for the optimal waiting time:

1. $D_{x 1}$ for a type 1 farmer who had not defaulted before

2. $D_{x 2}$ for a type 2 farmer who had not defaulted before

3. $D_{Y 1}$ for a type 1 farmer who had defaulted before

4. Dy2 for a type 2 farmer who had defaulted before

The optimal number of days for a type 1 farmer who had not defaulted before is given by $P\left[V_{b 1}+R\right]+(1-P)\left[\left(D_{x 1} / X\right) * V_{m 1}+\left(1-D_{x 1} / X\right) * V_{b 1}\right]=V_{b 1}$, where $P$ indicates probability of waiver and $\mathrm{R}$ the amount to be repaid to the bank. It leads to

$$
D_{X 1}=X R P /(1-P)\left(V_{b 1}-V_{m 1}\right),
$$


where $V_{b 1}-V_{m 1}$ represents the opportunity cost of foregoing the bank loan for a type 1 farmer. The optimal waiting time increases in $X$ (the maximum grace period allowed by the bank to the non-defaulters) and $\mathrm{P}$ (probability of a waiver). It decreases in the opportunity cost of foregoing the bank loan. Interestingly, R (the loan repayment amount) has a neutral effect on the optimal waiting period. Since all loan amount is invested in production in our model, $\mathrm{R}$ and the opportunity cost $V_{b 1}-V_{m 1}$ increase proportionately. Intuitively, loan volume does not affect the decision how long to keep a loan outstanding, because a loan and the opportunity cost of not getting the loan if the loan payment is delayed have equal but opposite effects on the decision.

Similarly, $D_{x 2}=X R P /(1-P)\left(V_{b 2}-V_{m 2}\right)$,

where $V_{b 2}-V_{m 2}$ represents the opportunity cost of foregoing the bank loan for a type 2 farmer who has not defaulted before. Note that $V_{b 1}-V_{m 1}>V_{b 2}-V_{m 2}$; the opportunity cost of foregoing the bank loan is greater for a type 1 firm. Therefore, $D_{x 2}>D_{x 1}$. Intuitively, a type 2 farmer can afford to take longer to pay off its current loan than a type 1 farmer, because it has less to lose if it loses access to bank loans in future. Similarly, $D_{Y_{2}}>D_{Y_{1} 1}$. In other words, in the group of past defaulters as well as non-defaulters, it is the worse type of farmers who will take longer to pay off their current debt.

Similarly, the optimal waiting period for type 1 and type 2 defaulters are given by replacing $X$ with $Y$ in (1a) and (1b) above.

Note that $D_{X 1}>D_{Y 1}$ and $D_{X 2}>D_{Y 2}$; it follows simply from $X>Y$. If $D_{X 1}$ (waiting time for good farmers who did not default) and $D_{Y_{2}}$ (waiting time for bad farmer who defaulted) could be ranked, we would have a complete ordering of the four optimal waiting periods. However, this ranking depends on the respective extension periods and the opportunity costs. A nondefaulter type 1 farmer gets an extension period of $X$ days, but has a higher opportunity cost of $V_{b 1}-V_{m 1}$ to worry about. A defaulter type 2 farmer gets fewer days of extension $\mathrm{Y}$, but also has a lower opportunity cost of $V_{b 2}-V_{m 2}$. Thus if $X / V_{b 1}-V_{m 1}>Y / V_{b 2}-V_{m 2}$, then $D_{X 1}>D_{Y 2}$. Otherwise, the opposite holds. Hence

If $X / V_{b 1}-V_{m 1}>Y / V_{b 2}-V_{m 2}$, then $D_{X 2}>D_{X 1}>D_{Y 2}>D_{Y 1}$

On the other hand, if $X / V_{b 1}-V_{m 1}<Y / V_{b 2}-V_{m 2}$, then $D_{X 2}>D_{Y 2}>D_{X 1}>D_{Y 1}$

Our data will indicate whether (2) or (3) holds for our sample of observations. 


\section{Empirical implications}

1. From the conditions for the optimal number of days in (1), $D$ is positive for any given farmer when $\mathrm{P}$ is positive and the bank gives an extension ( $\mathrm{X}$ or $\mathrm{Y}$ ). Therefore, if the past debt waiver creates expectations of another debt waiver, we should observe that all farmers in our sample regardless of type (1 or 2 ) or credit history (defaulter or non-defaulter) take longer to pay off their current debt in the post-waiver period. Alternatively, if a longer debt repayment period is observed, it will indicate that the farmers assign a non-zero probability to the next debt waiver at $\mathrm{t}=1$.

2. (a) If (2) above holds, it is optimal for the no-waiver farmers (non defaulters) irrespective of their type to take longer than both full-waiver and partial-waiver farmers (defaulters). Since past default status is empirically observable, it offers a clear empirical prediction.

(b) On the other hand, if (3) holds, then type 2 farmers, regardless of their past default status, take longer than type 1 farmers. Since type is not empirically observable, there is no clear empirical prediction. The results of a test that separates past defaulters from nondefaulters could be inconclusive.

3. Since all defaulters get the same extension ( $Y$ days), full-waiver and partial waiver farmers will be observed to delay payment by the same length of time beyond the due date, provided the proportions of type 1 and type 2 farmers are the same in both groups, even though they belong to very different size groups.

4. The condition for the optimal number of days to keep a loan outstanding in (1) indicates a negative association with the opportunity cost of losing bank credit. Since this opportunity cost in our framework is proportional to the value of the output of a farmer, we should empirically observe a negative association between the time taken by a farmer to pay off his bank debt and his production.

5. Loan volume does not affect the decision to keep a loan outstanding. It is probably the most startling implication of our model. However, the intuition is quite simple. Since all loans are invested in production in our model, loan amount and the opportunity cost of losing the bank credit increase proportionately. A loan and the opportunity cost of not getting the 
loan if the loan payment is delayed have equal but opposite effects on the decision how long to wait.

6. The bank loan officers, rationally anticipating an adverse change in borrower behavior in the post-waiver period, will be observed to ration credit and reject new loan applications from their existing clients. Further, the probability of a loan application rejection is significantly higher for the past defaulters. They are more likely to be type 2 farmers who present a higher risk of defaulting again. Even if they are able to pay off the new loans, given $D_{Y 2}>D_{Y 1}$, they are more likely to take longer to do so since their opportunity cost of foregoing a bank loan is lower.

\section{Data}

For all our empirical work in this paper we use a loan account level dataset obtained from an Indian public sector bank. Established more than seventy years back, the bank has a pan-India presence and operates more than a thousand branches. As of 31st March, 2012, the balance sheet size of the bank was INR 1183 billion (USD 21.5 billion). Net profits for the year 2011-2012 stood at INR 12.98 billion (USD 236 million).

\section{A. Transaction records}

The original dataset includes account level data for about sixteen thousand farmers who are customers of the bank and have received crop loan. The final sample includes 12,645 farmers for whom we have complete transaction records during the period October 2005 - May 2012. The farmers belong to 4 districts of the state of Andhra Pradesh in India ${ }^{15}$. The bank has a total of 9 branches in those districts. As typical of agricultural credit, the loans are short term loans, typically payable within the year. They fall under priority sector guidelines issued by the $\mathrm{RBI}$ and carry a subsidized interest rate. The loans are mostly fully collateralized, with land being the standard collateral asset. A state level bankers committee, comprising the state government representatives and senior bankers in the state, issues guidelines regarding collateral requirements.

\footnotetext{
${ }^{15}$ The districts are Karimnagar, Khammam, Mahbubnagar, and Medak.
} 
The transactions records of the farmers in the sample include the date of each transaction, a description of the transaction, type of the transaction (debit or credit), transaction amount, account balance before the transaction and after. The description of the transaction is sufficiently detailed for us to understand the exact nature of the transaction. With the help of the description and other variables, we are able to determine when a particular loan was taken, the amount of the loan, the interest and other charges like maintenance charge, legal notice charge etc., and when the loan was repaid and how long was the payment period.

The loan waiver scheme required the banks to publish detailed information about the beneficiaries of the program on their notice boards and websites. The information included size of their land holding. We have collected land holding information for the beneficiaries of the scheme, including full-waiver and partial-waiver groups. However, we do not have land holding information for the no-waiver group; the banks were not required to publish this information. In our empirical tests, whenever required, we have used other proxies for their size.

\section{B. Other data}

We have collected information about annual production of food grains for the districts in question during the period 2005 -2011. Rice was by far the most important crop while wheat, ragi and jowar were also cultivated. The other district-level data we use in our tests are annual rainfall and annual bank credit flow into the district. We also use consumer price index for agricultural laborers published monthly by the Indian government. The following chart lists the other data and their sources.

\begin{tabular}{|l|l|}
\hline \multicolumn{1}{|c|}{ Data } & \multicolumn{1}{|c|}{ Source } \\
\hline District-level foodgrains production & Department of Economics and Statistics, Andhra Pradesh \\
\hline District-level rainfall & Department of Economics and Statistics, Andhra Pradesh \\
\hline District-level bank credit flow & IndiaStats.com \\
\hline Inflation & IndiaStats.com \\
\hline
\end{tabular}




\section{Descriptive Statistics:}

We classify the 12,645 farmers in our final sample into three categories based on the benefits they received from the debt waiver scheme. Full-waiver farmers are those who had less than 2 hectares of land pledged as collateral (satisfying the condition for small and marginal farmers per the RBI), and had overdue farm loan on the cut-off date (February 29, 2008). Partial-waiver farmers are those who had 2 hectares or more land pledged and had overdue credit on the critical date. They qualified for partial (25\%) loan relief conditional on repayment of the remaining $75 \%$ within a year. No-waiver farmers did not have any overdue loan on the day. The threshold of 2 hectares is a pre-existing limit set by the RBI to separate small and marginal farmers from the rest. The fact that the limit was not introduced by the debt waiver scheme should allay endogeneity concerns. 8064 farmers fall under the full waiver category, 2209 farmers under the partial waiver category and 2374 farmers under the no waiver category. Table 1 presents the summary statistics of the data.

\section{Table 1 here}

As mentioned above, we have land holding information for only full-waiver and partialwaiver groups, though not in all cases. As expected, the average (median) land holding of the full-waiver farmers is much smaller, 0.99 (1) hectare, than the partial-waiver farmers, 5.66 (3.11) hectares.

We compute the number of days the last loan taken by the farmers in our sample prior to the waiver was outstanding as of February 29, 2008. Not surprisingly, the number is much higher for the full and partial waiver groups than the no-waiver group. The average (median) number of days is 434 (443) for the full-waiver farmers, 419 (405) for the partial-waiver farmers, and 254 (251) for the no-waiver farmers. Considering that these loans are predominantly crop loans with tenure of less than a year, the data clearly shows that the full and partial waiver farmers were indeed defaulters whereas the no - waiver farmers were not in default. 
We also determine the amount of debt outstanding for the farmers in our sample as of February 29, 2008, as well as the average amount of loans taken by them from the beginning of the sample period (October, 2005) until that date. All the reported statistics (average, median, Q1, and Q3) for both amounts show a uniform pattern. In each case the numbers are the lowest for full-waiver farmers and the highest for partial-waiver farmers, with the no-waiver farmers falling somewhere between the two groups. The reasons are obvious. Full-waiver farmers have less land holdings, the standard collateral for credit, than partial-waiver farmers. No-waiver group has a mix of both small and large farmers. We keep this distinction in view in all our tests so that an important unobservable factor, namely the size of no-waiver farmers, does not bias our results.

\section{Empirical strategy}

\section{A. Different specifications}

In most of our tests, we compare the number of days the loans were outstanding in the pre-waiver period with the number of days the loans were outstanding in the post-waiver period for a given farmer in our sample. We consider four specifications to compare the pre and post waiver repayment patterns.

a. Comparison between all loans before and all loans after the waiver.

b. Comparison between the last loan before and all loans after the waiver.

c. Comparison between the last loan before and the first loan after the waiver.

d. Comparison between the last loan before and the last loan after the waiver in our dataset.

We start with specification (a) in order to get a sense of average change in repayment behavior in the post-waiver period compared to the pre-waiver period. We avoid being selective and use all loan data for which information regarding the date of borrowing is available. However, it can be argued that since the debt waiver scheme took into account only the last loan before the waiver, it is appropriate to compare the number days the last loan before the waiver was outstanding with the number of days the average loan taken in the postwaiver period was outstanding. We do this in specification (b). It could also be argued that the 
impact of the waiver would be more pronounced on the first loan after the waiver. Successive loans may be affected less by the waiver and more by other circumstances in the post-waiver period. To investigate this issue, we use specification (c). For the sake of completeness and also to assess the latest repayment behavior of the farmers available from our dataset, we use specification (d). Intuitively, under scenario (c) we should expect the largest difference in the number of loan outstanding days in the two periods. If the waiver influences the loan repayment behavior of the farmers, the influence should be felt the most in the case of the first loan after the waiver. For similar reasons, the results should be the weakest under scenario (d). With time, the influence should dissipate.

\section{B. Dependent variable}

The number of days outstanding for a loan in the post-waiver period compared to the post-waiver period is the appropriate dependent variable for our regression models. Using a binary classification, such as overdue/not overdue, is not only more limiting than a continuous variable, but also not very appropriate in our case. The default status of a loan is also not a very meaningful variable for our purpose. Since every farmer in the full and partial waiver group was a defaulter in the pre-waiver period, any test is bound to register some improvement for them in the post-waiver period. In some cases we are not certain about the exact due date for a loan. Though crop loans are usually given for a year, the maturity varies for certain crops. However, we do use a proxy for default in certain tests, though we are careful not to lose sight of its limitations.

In all specifications we compute the number of days a loan remains outstanding as follows. For those loans where the borrowing as well as repayment happened within the pre waiver period, we simply find the gap in days between the borrowing and the repayment dates. We do similar calculations for loans which were taken and repaid in the post-waiver period. The pre-waiver period loans which remained outstanding as of February 29, 2008, were either waived or repaid in the post-waiver period, though in some cases the loans were not repaid within our sample period. For all such loans we take February, 29, 2008 as the termination date in our tests. For each farmer in our sample, we start counting the post-waiver period loans from the first loan borrowed after February, 29, 2008. For loans outstanding as of February 28, 
2011, we treat February 28, 2011 as the last date of the loans in most of our tests. We have chosen February, 2011, as the comparable point in time in the post-waiver period for two reasons. First, since the farmers are likely to have similar harvest and sowing seasons every year, their repayment schedules are likely to be the same every year too. Therefore, it is meaningful to compare February 2008 and February of any year post 2008. We have chosen the year 2011 because it happens to be the last year of our sample period (2005 - 2012) for which we have district level production data. As a robustness measure, we run tests using all months of 2011 as the terminal dates for loans taken in the post-waiver period. Changing the terminal dates does not change our results in any way.

\section{Independent variables}

Among the independent variables in our tests, a variable separating the loans in the post-waiver period from the pre-waiver period is important. It takes the value of 1 for the post waiver period, and 0 otherwise. Depending on the test, other independent variables are included. Loan volume, landholding (standard collateral for crop loans), and output quantity are normally important variables in a farmer's payment decisions and, depending on data availability, are included as control variables in our tests. As discussed above, our model implies that loan volume should not affect the decision how long to keep a loan outstanding, because a loan and the opportunity cost of not getting the loan if the loan payment is delayed have equal but opposite effects on the decision. Since landholding has a high positive correlation with loan size, it also has a neutral effect. The condition for the optimal number of days to keep a loan outstanding in (1) indicates that the length of time a farmer chooses to keep his loans outstanding will decline in his output, since output is proportional to the opportunity cost.

Since our tests involve before and after comparisons, if the control variables remain fairly static over a length of time for a farmer in rural India, they should not economically influence the results much. Landholdings of farmers change slowly, if at all. Since loan volume for a farmer is typically tied to his landholding, land being the standard collateral, and output is generally dependent on land, they do not change much from the pre-waiver to the post-waiver period either. Our test results confirm this intuition. This also means that our test results remain reliable in cases where we do not have data for the control variables. We have loan 
information for each farmer in our sample, it being one of the sample selection criteria. However, we have landholding information for only full-waiver and partial-waiver farmers, and that too not in all cases. However, since land is typically pledged as collateral for loans, if necessary loans may serve as a suitable proxy for landholdings. Unfortunately, crop production data at the level of individual farmers is not available. The most granular information available is crop production in the district in which a farmer resides. We also use rainfall data at the district level and agricultural credit flow to the districts as other control variables.

During the sample period (2005 - 2011), India experienced high annual inflation rates. Given our multiple-year sample period, controlling for inflation is important to ensure the reliability of test results. We use monthly consumer price index for agricultural laborers (CPIAL) to control for changing agricultural prices over the sample period.

\section{Results: Borrowers' response to debt waiver}

We proceed in the following manner. We begin by comparing the farmers' repayment behavior, as measured by the number of days a loan remains outstanding, in the pre and post waiver periods within each of the three groups of the farmers: full-waiver group, partial-waiver group, and no-waiver group. We use univariate as well as multivariate tests. The tests in this part do not claim causality. We then proceed to comparisons between groups in the pre and post-waiver periods in a difference-in-difference setting. The results suggest that the debt waiver program caused a marked deterioration in the loan payment behavior of the farmers across the board, but especially in the case of the no-waiver group. Branch fixed effects are included in all tests. The standard errors are adjusted for clustering at the branch level.

\section{A. Within group comparisons between pre and post waiver periods}

We start with a univariate comparison of the average number of days loans for each group of farmers were outstanding during the pre-waiver period and the average number of days the loans were outstanding in the post-waiver period. We conduct a simple meandifference test of days outstanding before and after February, 2008. The results are reported in Table 2 below.

Table 2 here 
For all three groups, the mean number of days for which the last loan is outstanding is significantly higher in the post-waiver period: by 22 days for the full-waiver group, 25 days for the partial-waiver group and as much as 197 days for the no-waiver group. The difference is significant in all three cases at $1 \%$ level. The results confirm prediction (1) of our model discussed in section IV before. Exhibit 1 below presents the results diagrammatically.

\section{Exhibit 1 here}

The typical maturity period of a crop loan is a year, reflecting the fact that there is usually one production cycle for a crop in a given year. The data in Table 2 indicates that the full-waiver farmers and partial waiver farmers were indeed in default before the debt waiver program, with loans outstanding for 434 and 456 days respectively. This fact qualified their debt for waiver. On the other hand, no-waiver farmers had their loans outstanding for 254 days on average and missed the waiver. In the post-waiver period this number balloons to 451 days.

We proceed to multivariate tests for within-group comparisons and estimate the following regression model for each of the three groups:

Days $_{i j t}=\alpha+v_{b}+\delta$ PostO $+B_{1}$ Loan $_{i j t}+B_{2}$ Land $_{i t}+$ B $_{3}$ Production $_{d t}+B_{4}$ Rain $_{d t}+B_{5}$ Credit $_{d t}+$ B $_{6}$ Inflation $_{t}+\varepsilon_{i t}$

The dependent variable Days $s_{i j t}$ is the number of days loan $\mathrm{j}$ taken by farmer $\mathrm{i}$ remains outstanding in the pre waiver period $(t=0)$ and post waiver period $(t=1)$. The independent variable of interest, Post08, takes value of 1 if the loan was taken in the post-waiver period. $\operatorname{Loan}_{i j t}$ and Land ${ }_{i t}$ are farmer-specific control variables. Loan $i j t$ represents the amount of loan $\mathrm{j}$ taken by farmer $\mathrm{i}$ in the pre-waiver period $(\mathrm{t}=0)$ and in the post-waiver period $(\mathrm{t}=1)$. Land $_{i t}$ is the landholding of farmer $i$ in the two periods. Production ${ }_{d t}$, Rain $_{d t}$ and Credit $_{d t}$ are districtspecific control variables and refer to the district $d$ that farmer $i$ resides in. They represent the total food grains production, rainfall, and credit flow in the district in the year loan $\mathrm{j}$ was taken. Inflation $_{t}$ indicates inflation rates based on monthly consumer price index for agricultural laborers $(C P I A L)$ in the pre-waiver period $(t=0)$ and in the post-waiver period $(t=1)$. Branch fixed effects $v_{b}$ are included in all specifications, and standard errors are cluster-adjusted at the branch level. 
We estimate equation (4) for all four specifications mentioned above. The results for specification (a) are reported in Table 3A below. Column (1) reports the results for the fullwaiver group, while column 2 and 3 report the results for partial-waiver and no-waiver groups respectively.

\section{Table 3A here}

The results show that the average number of days the loans remain outstanding increases in the post-waiver period for all three groups. In two of the three cases, the differences are statistically significant. The increase is 131 days (significant at $10 \%$ level) for the full-waiver group and 353 days (significant at 1\% level) for the no-waiver group. For the partial waiver group the co-efficient of the post waiver dummy is statistically insignificant. In all three cases the prediction of our model that the time that a loan remains outstanding increases in the post-waiver period for all categories of borrowers is confirmed. As long as the borrowers attach a non-zero probability to the next waiver, they use the grace period extended by the bank to keep their loans outstanding longer.

In tables 3B, 3C and 3D we repot the results for specifications (b), (c) and (d) respectively. The results are very similar to specification (a). There is an across the board increase in the number of days loans remain outstanding in the post-waiver period. In all cases, the increase is the highest for the no-waiver group. While the increase in the number of days in the post waiver period across the four scenarios ranges between $72-131$ for the full waiver group, and 52- 215 days for the partial waiver group, the coefficients are not always statistically significant. By contrast, the corresponding range for the no waiver group is $172-398$, and the coefficients are always significant at $1 \%$ level. Note that the results for the Post0 8 variable reported in Table $3 \mathrm{C}$ are the strongest, as we had predicted. For the partial-waiver and nowaiver groups, the difference in days outstanding between the two periods is 215 and 398 respectively (both significant at $1 \%$ level), while it is 72 for the full-waiver group (significant at $5 \%$ level). The influence of the waiver is felt the most for the first loan after the waiver. For similar reasons, the results are the weakest under scenario (d) where we consider the last loan in the post-waiver period. The results here also are as we had predicted above.

Tables 3B, 3C, and 3D here 
The coefficients for the Loan variable are zero in all cases, and statistically insignificant in all but one. Similarly, the coefficients of the Land variable are insignificant in most cases, and economically negligible when significant. Consistent with the prediction of our model, loan volumes and landholdings do not appear to influence repayment behavior of the farmers.

Note that the coefficients for the Production variable are mostly negative as predicted by our model, though not always statistically significant. They are also not economically significant which is explained by the fact that the outputs of the farmers in our sample do not change much between the pre-waiver and post-waiver periods.

\section{B. Between group comparisons}

We now proceed to comparisons between the three groups of farmers with respect to the number of days their loans remain outstanding before and after the 2008 loan waiver program. We adopt a difference-in-difference testing strategy. The two differences are

a) number of days a loan remains outstanding before or after the waiver; and b) waiver status: full, partial or none.

The following regression model tests the difference in difference Days $_{i j t}=\alpha+v_{b}+\delta_{1}$ Post08 $+\delta_{2}$ Fullwaiver $+\delta_{3}$ Partialwaiver $+\delta_{4}$ Post08*Fullwaiver + $\delta_{5}$ Post08 $^{*}$ Partial waiver $+b_{1}$ Loan $_{i t}+b_{2}$ Production $_{d t}+b_{3}$ Rain $_{d t}+b_{4}$ Credit $_{d t}+b_{5}$ Inflation $_{t}+\varepsilon_{i t}$ (5)

The dependent variable Days $i j t$ and the independent variables of interest Post08 have the same interpretation as in equation (4) before. Fullwaiver, Partialwaiver and their interaction terms with Post08 are additional variables of interest. Fullwaiver (Partialwaiver) takes a value of 1 if the farmer belongs to the full-waiver (partial-waiver) group. The control variables Loan $_{i j t}$ Production $_{d t}$, Rain $_{d t}$ Credit $_{d t \text {. and Inflation }}$, have the same interpretation as in equation (4) before. Since we do not have landholding information for the no-waiver group, th Land $_{i t}$ variable is omitted in this model. As before, branch fixed effects $v_{b}$ are included in all specifications, and the standard errors are cluster-adjusted at the branch level. The results are reported in Table 4 below.

Table 4 here 
In columns 1, 2, 3 and 4 of Table 4, we report the results of specifications (a), (b), (c) and (d) respectively. In all four specifications, Post08 (denoting loans taken after the waiver) is positive and significant. All groups keep their loans in the post-waiver period for a longer period. From Table 4, column 1, using specification (a), the increase is 278 days for the nowaiver group (included in the constant term), (278-185) or 92 days for the full-waiver group, and $(278-166)$ or 112 days for the partial-waiver group. The results confirm prediction (1) of our model and, in the process, reaffirm the within-group results in Tables 2 and 3 before. The results also confirm our earlier finding that within-group differences in days outstanding before and after the waiver are the strongest under scenario (c) where we compare the first loan after the waiver with the last loan before the waiver. In this scenario, the differences are (384 - 267) or 117 , (384 - 244) or 140, and 384 for the full-waiver, partial-waiver, and no-waiver groups respectively.

More interestingly, the difference in the number of days a loan remains outstanding between the two groups that received the waiver benefit and the group that did not receive the benefit changes significantly from the pre-waiver to the post-waiver group. The coefficients of the two interaction terms in Table 4, column 1, indicate that the no-waiver group keeps its loans outstanding for 185 (165) more days than the full-waiver (partial-waiver) group in the post-waiver period compared to the pre-waiver period. In columns 2, 3 and 4, we get similar results using specifications (b), (c) and (d) respectively. The additional number of days for the no-waiver group compared to the full-waiver (partial-waiver) groups in the post-waiver period are 259 (249), 267 (244) and 245 (208) respectively under specifications (b), (c) and (d). The results are significant at $1 \%$ level in all specifications. From the results of within group comparisons in tables 2 and 3 before, all three groups keep their loans outstanding for more days in the post-waiver period. Here we probe further and note that the no-waiver group, which previously had better loan repayment records than the other two groups, and consequently did not qualify for debt relief, displays worse records than the other groups in the 
post-waiver period. Their behavior is exactly consistent with prediction (2) of the model discussed above. ${ }^{16}$

It is also interesting to compare the debt repayment behavior of the full-waiver and partial-waiver groups in the post-waiver period, the two groups that had defaulted in the past and benefited from the past debt relief program. The difference in the additional number of days they keep their loans outstanding in the post-waiver period compared to the pre-waver period is statistically insignificant in each of the four specifications. The p-values of the difference between the coefficients of the interaction term Fullwaiver*Post08 and the corresponding interaction term Partialwaiver*Post0 8 are $0.46,0.65,0.59$. and 0.34 in the four cases. The results confirm the prediction of our model that the additional length of time that the two groups keep their loans outstanding will be similar, since they get the same extension period based on their similar past credit history ${ }^{17}$.

Finally, the coefficients of the Loan variable are zero in all four specifications. The coefficients of the Production variable are negative in each case, though significant in only two of them. Both results are consistent with our predictions.

\section{Probability of Default}

it could be argued that frequency of default is also an appropriate indicator of deterioration of credit culture, in addition to the number of days a loan remains outstanding, though we have noted some of its limitations earlier. Unfortunately, we do not have loan due dates in all cases in our dataset. However, since all loans in our sample are crop loans which mostly have one year maturity period, we proceed by taking 365 days as the tenure of the loans in our sample. We estimate the following linear probability model as a robustness check on the results of equation (5) before.

Default $_{i j t}=\alpha+v_{b}+\delta_{1}$ Post08 $+\delta_{2}$ Fullwaiver $+\delta_{3}$ Partialwaiver $+\delta_{4}$ Post08*Fullwaiver + $\delta_{5}$ Post08 $^{*}$ Partial waiver $+B_{1}$ Loan $_{i t}+B_{2}$ Production $_{d t}+B_{3}$ Rain $_{d t}+B_{4}$ Credit $_{d t}+B_{5}$ Inflation $_{t}+\varepsilon_{i t}(5 \mathrm{~A})$

\footnotetext{
${ }^{16}$ The results are consistent with equation 2 in section IV above. They also imply that $X / V_{b 1}-V_{m 1}>Y / V_{b 2}-V_{m 2}$, $a$ condition necessary for equation (2) to hold. Please see our discussion in section IV.

${ }^{17}$ The results also indicate that the proportions of type 1 and type farmers are similar in two groups (see our discussion in section IV before).
} 
Note that equation (5A) differs from equation (5) above only in respect of the dependent variable Default $\mathrm{i}_{\mathrm{ijt}}$ which takes value 1 if the loan $j$ for farmer $i$ is outstanding for more than 365 days, and 0 otherwise, for a pre-waver period loan $(t=0)$ or for a post-waiver period loan $(t=$ 1). The estimation results are reported in table 5 below:

Table 5 here

In columns 1, 2, 3 and 4 of Table 5, we report the results of specifications (a), (b), (c) and (d) respectively. As before, in all four specifications Post08 is positive and significant. In the post-waiver period the no-waiver group included in the constant term exhibits a significantly higher probability of defaulting in all specifications to the extent of $0.3-0.6$. The interaction terms Fullwaiver*Post08 and Partialwaiver*Post08 are negative and significant in all specifications, implying that full-waiver and partial-waiver groups have a lower probability of defaulting in the post-waiver period than the no-waiver group. In fact, in their case the probability of default in the post-waiver period decreases in all specifications. For example, in scenario (a) the decrease in probability is 0.2 for both full-waiver and partial-waiver groups. However, it should be noted that since both groups had defaulted in the pre-waiver period, in their case the change in default probability in the post-waiver period can be only in the negative direction.

\section{Alternative explanations}

\section{A. Does size explain debt payment behavior in the post-waiver period?}

Are missing variables in regression model (5) impacting different groups of farmers in the sample differently, and leading to the observed results in Table 4 before? The size of landholdings of the farmers is a candidate for such variables. We know from the summary statistics in Table 1 that the three groups of farmers have quite different landholdings. The fullwaiver farmers appear to be the smallest and the partial-waiver farmers the largest, while the no-waiver farmers, for whom we not have landholding information, appear to be in the middle. The regression model (5) which led to the results in Table (4) does not control for the farmers' landholdings, since we do not have the information for the no-waiver group. However, the landholding of a given farmer in our sample is usually the same in the pre and post-waiver 
periods, and therefore not having this information would appear not to matter much in a difference-in-difference setting. But, there could be time varying unobservable factors related to landholding that are different for different farmers who own plots of similar size. For example, a farmer who owns the same plot of land in the pre and post-waiver periods may cultivate different crops in the two periods.

To address this problem, we proceed as follows. First, we use loan amount for a farmer as a proxy for the size of his landholding, since land is the standard collateral used for crop loans. We classify the farmers in our sample into quartiles based on their average loan amount in the pre-waiver period. In the second step, we estimate regression model (5) for sub-samples with similar loan amounts, and verify if the difference-in-difference results observed in Table 4 hold for the sub-samples. This procedure results in the following four groups;

Group 1: average loan amount up to INR 11,266 (quartile1 of average loan amounts in the prewaiver period)

Group 2: average loan amount more than INR 11,266 but not exceeding 21,000 (the median of loan amounts in our sample)

Group 3: average loan amount more than INR 21,000 but not exceeding 35,000 (quartile 3 of loan amount)

Group 4: average loan amount exceeding INR 35,000

We run the difference-in-difference regression in model (5) on each group separately. The results are reported in table 6 below. In each group, the no-waiver farmers appear to take significantly longer to pay off their current debt than the full and partial-waiver farmers in the post-waiver period compared to the pre-waiver period. The coefficients of the interaction Fullwaiver*Post08 variable are negative in all specifications and significant at $1 \%$ level in scenarios (a), (b) and (c) and 5\% level in scenario (d). The results indicate that, regardless of the loan size, the full-waiver farmers keep their loans outstanding for fewer days than the nowaiver farmers in the post-waiver period compared to the pre-waiver period. The coefficients of the interaction terms Partialwaiver*Post08 are also negative and significant in all 
specifications. The findings amply confirm the results in Table 4 before. We conclude that unobservable factors relating to size are not driving the results in Table 4 above.

\section{Table 6 here}

As in Table 4, the coefficient of the Loan variable is zero in all cases in Table 6 . The results match perfectly the prediction of our model. ${ }^{18}$ Also consistent with our model, the coefficients of the Production variable are negative for three groups, though they are not significant in any specification. The coefficient is positive and significant for group 4, but economically negligible.

\section{B. Does past debt relief explain debt payment behavior in the post-waiver period?}

In our model the expectations of a debt relief program coupled with the credit history of the borrowers, which prompt the banks to grant longer grace periods to those borrowers who had not defaulted before, drive our results. However, an alternative explanation is suggested in Randal et al (1998). The paper argues that distressed bonds increase in value more than the other bonds following restructuring, because the issuers of distressed bonds have lower leverage and higher net worth following restructuring than the other firms ${ }^{19}$. Following this argument, the borrowers in our sample who received debt relief, with their past debt service obligations wiped out, should be able to pay off their current loans sooner than those in the nowaiver group. However, while this argument is logical, whether it is also realistic needs verification with data. To that end, we compare the debt repayment behavior of the full-waiver farmers and the partial-waiver farmers in the post-waiver period. If the above argument holds, we should observe that the full-waiver farmers in our sample take less extra time to make debt payment in the post-waiver period than the partial-waiver farmers who got only $25 \%$ of their loan written off, controlling for all relevant factors. Recall that, based on the results in Table 4 which included all three groups, full-waiver and partial-waiver farmers appear to take about the same number of days longer in the post-waiver period than in the pre-waiver period. However,

\footnotetext{
${ }^{18}$ Though loan size is used to partition the original sample, within each partition the size of loan for the farmers varies. Hence our tests continue to use loan volume as an explanatory variable.

${ }^{19}$ Note that the argument in Randal et al (1998) is consistent in spirit with the debt overhang and risk-shifting arguments in Jensen and Meckling (1976) and Myers (1977). Their models also suggest improvement in productivity and investment arising from a decline in debt burden.
} 
landholdings of the farmers were not controlled for in that test since we do not have the landholding data for the no-waiver group. We estimate the following regression;

$$
\begin{aligned}
& \text { Days }_{i j}=\alpha+v_{t}+\delta_{1} \text { Post0 }+\delta_{2} \text { Partialwaiver }+\delta_{3} \text { Post0 }^{*} \text { Partial waiver }+B_{1} \text { Loan }_{i t}+B_{2} \text { Land }_{i}+ \\
& \text { B }_{3} \text { Production }_{d t}+b_{4} \text { Credit }_{d t}+B_{5} \text { Rain }_{d t}+b_{6} \text { Inflation }_{t}+\varepsilon_{i t}
\end{aligned}
$$

The regression model (6) is similar to the regression model (5) before which compared all three groups of farmers except for two changes. No-waiver farmers are excluded by design, and the full-waiver farmers are included in the constant term. The other change is that the model controls for the landholding of the farmers, because the average landholding is quite different between the two groups of farmers and we have landholding information for both groups.. The results are reported in Table 7A below.

\section{Table 7A here}

As in Table 4 before, the results are presented for four different specifications. The results for the interaction term Partialwaiver*Post08 indicate that, except in specification (d), there is no statistical difference in the repayment behavior of partial-waiver farmers and fullwaiver farmers in the post-waiver period compared to the pre-waiver period. In fact, in specifications (a) and (b), the coefficients, even though insignificant, indicate that the partial waiver farmers take less time than the full waiver farmers in the post waiver period compared to pre waiver period. Only in specification (d) the interaction term is positive and significant. However, specification (d) compares the last loan before the waiver with the last after the waiver. In this case, the post-waiver loan repayment could very well be affected by other factors in the intervening three years from 2008 to 2011. The results do not support the suggestion that beneficial changes in leverage or net worth of the borrowers who receive full debt relief motivate them to pay off their loans sooner than the others in the post-waiver period. The results actually support the prediction of our model where the farmers make their repayment decisions strategically, and to that end use the extensions given by the bankers. The two groups get similar extensions because of their similar past credit history.

As a robustness check on the estimation results of equation (6) discussed above, we estimate a modified version of the equation for farmers with similar landholdings: 
Days $_{i j}=\alpha+v_{t}+\delta_{1}$ Post08 $+\delta_{2}$ Partialwaiver $+\delta_{3}$ Post0 $^{*}$ Partial waiver $+B_{1}$ Loan $_{i t}+B_{2}$ Production $_{d t}$ $+b_{3}$ Credit $_{d t}+B_{4}$ Rain $_{d t}+B_{5}$ Inflation $_{t}+\varepsilon_{i t}$

Note that landholding is dropped as a control variable in (7). Instead, we combine farmers with comparable landholdings in full and partial waiver groups into three mixed groups around the cut-off point of 2 hectares: (1) $1.8-2.2$; (2) $1.75-2.25$, and (3) $1.7-2.3$ hectares. The number of full-waiver and partial-waiver farmers in the three mixed groups are, respectively, 387 and 404, 392 and 427, and 429 and 443. In other words, the full-waiver and partial-waiver farmers are almost equally represented in the new groups. We estimate model (7) for each group. Note that the tests here are in the same spirit as regression discontinuity tests. The results are reported in Table 7B below. The coefficients for the interaction term Partialwaiver ${ }^{*}$ Post08 are now positive in all specifications, but they are all insignificant. The results suggest that the farmers with similar landholdings effectively take the same number of days to pay off their loans in the post-waiver period, even though some of them received full and the others partial debt waiver before. The results confirm our conclusions from Table 7A before.

\section{Table 7B here}

As in all cases before, in Tables 7A and 7B too the coefficients of the Loan variable are zero and the coefficients of the Production variable have a negative sign in all specifications, consistent with the predictions of our model.

\section{Results: Bankers' response to debt waiver}

In this section we look at the reaction of the loan officers to the debt waiver as indicated by their future lending decisions. The debt waiver circular clearly states that the farmers who had their loans waived should not be discriminated against in future loan decisions. The intention was to make sure that the debt-ridden farmers should get new credit and should be able to carry on their agricultural activity as before. However, the aversion of the bankers in India to risky borrowers is well known (Bannerjee and Dufflo, 2008). 
We first investigate whether the farmers who defaulted earlier and received either full or partial loan waiver face a higher probability of rejection when they apply for new loans compared to those who did not default. We also test whether, in addition to the default status of the loan, the length of time a loan in default remains outstanding influences the probability of new loan rejection. We estimate the following Probit regression model:

Reject $_{i}=\alpha+v_{b}+\delta_{1}$ fullwaiver $_{i}+\delta_{2}$ Partialwaiver $+\varepsilon_{i t}$

The dependent variable Reject $_{i}$ is a dummy variable that takes value 1 if the loan account for farmer $i$ indicates new loans in the pre-waiver period but none in the post-waiver period ${ }^{20}$. As mentioned earlier, agricultural loans are covered under priority sector lending guidelines, and as such carry substantially below market rates of interest. Given that the farmers in our sample are mostly small, especially the full-waiver farmers, and face huge credit constraints, it is inconceivable that they would not have applied for a new priority sector loan. The independent variables have the same interpretation as before. The results are reported in Table $8 \mathrm{~A}$ below.

\section{Table 8A here}

The results in column 1 of Table 8A clearly show that the farmers who had defaulted before had significantly higher chances of not getting any new loans in three years after the debt waiver (which is when our sample period ends). Compared to the farmers who did not default and are included in the constant term in equation (8), the median full-waiver farmer has a $5.5 \%$ higher chance of not having a loan in the post waiver period. For the median partialwaiver farmer, the chance of not having a loan in the post-waiver period is approximately $19.9 \%$ higher than the no-waiver farmers.

In column (2) of the table we club full-waiver and partial-waiver farmers together in a single Default category, and test for the rejection probability of the borrowers in the combined category compared to the no-waiver farmers. As expected, we find that the median past defaulter has a nearly $8 \%$ higher chance of not having a loan in the post-waiver period than the no-waiver farmers.

\footnotetext{
${ }^{20}$ There are 1,022 such farmers in our sample, consisting of 533 full-waiver, 368 partial-waiver, and 121 no-waiver farmers. From Table 1 before, there are 8,064 full-waiver, 2,209 partial-waiver,, and 2,372 no-waiver farmers in our sample that had loans in both pre and post-waiver periods.
} 
The results in Table $8 \mathrm{~A}$ indicate that the partial-waiver farmers face higher rejection chances for new loans in the post-waiver period than the full-waiver farmers, when both groups are compared to the no-waiver farmers. We investigate this result further and directly compare the rejection probabilities for the two groups of defaulters. At the same time, we also attempt to determine how the two critical pieces of information in the borrowers' credit records - the default status and the number of days the last loan of a farmer was outstanding - contribute to the rejection probability of a new loan application in the post-waiver period and whether one of them dominates the other. To that end we estimate the following Probit regression model:

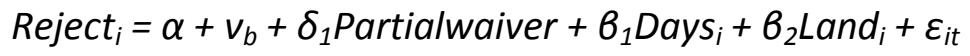

The results for three specifications with different controls are reported in three columns of Table 8B below. The results for the Partialwaiver variable are very consistent across the columns. Compared to the full-waiver farmers, new loan applications of the median partialwaiver farmer has a $10.1 \%$ percent higher chance of being rejected in column 1, 9.67\% higher chance in column 2 , and $9.73 \%$ percent higher chance in column 3 . The results are significant at $5 \%$ level in all three cases. The coefficients of Days is very small in all three cases, but positive and significant in column 1 , and negative and significant in column 3 where Days^ 2 appears as an additional control. However, the economic significance of the results is negligible throughout. In column 3, rejection probability decreases by $0.01 \%$ for an increase of 1 day from the median of the distribution. The coefficient of Days^2 is positive and significant, but virtually close to zero.

The results provide evidence that answers our queries. The borrowers in the partialwaiver group face a significantly higher chance of new loan rejection in the post-waiver period than the full-waiver borrowers. The length of time the last loan before the waiver has remained outstanding affects new loan rejection probability little. What matters to the bankers is the default status of a loan, in other words whether the last loan has been in default rather than by how many days. All the same, in column 3 the results for Days (negative and significant) and for Days $^{\wedge} 2$ (negative and significant), though both results are of little economic significance, seem curious at the first glance and call for investigation. The turnover point where the slope of Days 
turns from negative to positive is 393 days $^{21}$. It is a significant number. Note that it is very close to the sum of the average maturity of agricultural loans (365 days) and a grace period of 30 days. The results suggest that up to the turnover number of days the length of time a loan remains outstanding does not materially increase rejection probability. However, the number of days beyond the turnover point the probability increases, albeit minimally. The results make intuitive sense. The coefficient of the Land variable is negative but not significant, as in most cases before.

The estimation results of equation (9) are sharply different for the full and partial-waiver farmers. Naturally, we probe why and find an explanation. The debt waiver program of 2008 changed the existing debt burden of the two groups very differently. The full-waiver farmers had all their agricultural debt erased and, accordingly, entered the post-waiver period debt-free and stronger candidates for new loans. Partial-waiver farmers, on the other hand, had only $25 \%$ of their existing debt waived, and that too if they could pay off the remaining $75 \%$ on their own within a reasonable period of time. It is inconceivable that they had their own savings to dip into. If they did, they would not have defaulted in the first place. The typical alternative source of funds in such cases is private moneylenders who would charge a substantially higher rate of interest than the priority sector bank loans. Moreover, such loans would be "hard" loans, with strict repayment conditions, compared to bank loans which are typically softer for farmers. In other words, the partial-waiver farmers were not only considerably more debt-ridden than the full-waiver farmers but also had $75 \%$ of their existing bank loans replaced by loans which carried decidedly more onerous terms. Consequently, they were weaker candidates for future bank loans.

In Tables 8A and 8B above, we consider macro-rationing of bank loans whereby a certain proportion of the previous borrowers are denied any new bank credit. We now proceed to the related issue of micro-rationing whereby individual borrowers do not get their desired levels of credit, though they may get some new credit $^{22}$. For the rural borrowers who did qualify

\footnotetext{
${ }^{21}$ The value of Days $_{i}$ that represents the turnover point is given by $-b_{1} / 2 b_{2}$ where $B_{1}$ indicates the regression coefficient of Days $s_{i}$ and $B_{2}$ indicates the regression coefficient of Days ${ }_{i}{ }^{2}$.

${ }^{22}$ Ghosh, Mookherjee, and Ray (2000) discuss macro versus micro rationing.
} 
for new loans in the post-waiver period, how did the size of the new loans compare with the old loans after controlling for inflation in the intervening period? We compare new loans given to different groups of farmers in the post-waiver period compared to the pre-waiver period by estimating the following equation:

Loanamt $_{i t}=\alpha+v_{t}+\delta_{1}$ Post08 + B $_{1}$ Production $_{d t}+B_{3}$ Rain $_{d}+$ B $_{4}$ Credit $_{d}+$ B $_{2}$ Inflation $+\varepsilon_{i t}$

The dependent variable Loanamt ${ }_{i t}$ indicates the average new loans for farmer $i$ in the pre-waver period $(t=0)$ and the post-waver period $(t=1)$. The independent variables have the same interpretation as before. We run a separate regression for each group of farmers as the groups have landholdings of different size ${ }^{23}$. Table 9 below reports the results.

\section{Table 9 here}

From the table, the coefficient of Post08 is positive for the full-waiver and partial-waiver groups, and negative for the no-waiver group. However, none of the coefficients are statistically significant. In other words, the farmers who qualify for new loans in the post-waiver period essentially get the same amount of credit as before after controlling for inflation. Even then it seems curious that the coefficient of Post08 should be negative and much larger in absolute value $(10,907)$ for the no-waiver farmers who had not defaulted in the past compared to fullwaiver farmers $(2,673)$ and partial-waiver farmers (615). But there is an intuitive explanation. The bank loan officers would rationally anticipate that the loan repayment behavior of the nowaiver farmers would deteriorate significantly, in fact more so than the other groups. Since those farmers have not defaulted on their past loans, it would be very difficult for the loan officers to deny them new credit altogether, but not that difficult to micro-ration them.

\section{Concluding remarks}

Using a model as well as extensive empirical tests, in this paper we have investigated the effects of a large-scale debt relief program on the post-waiver debt repayment behavior of borrowers and creditors in a rural credit market. In our setting which captures actual conditions

\footnotetext{
${ }^{23}$ The only reliable proxy for landholding is loan amount itself from Table 6 before which of course cannot be used in this case.
} 
in many emerging economies, the farmers borrow from banks at a subsidized rate and from informal sources at a substantially higher rate, debt contract enforcement is imperfect, and political interventions in the credit market in the form of debt relief can happen even in normal states of the economy. The scope of our investigations has been comprehensive and has included all classes of borrowers: those who receive full debt relief, those who receive partial debt relief, and those who do not benefit at all from a relief program for overdue loans as they do not have any. Our model suggests, and our empirical tests have confirmed, that the effects are negative for all groups. The number of days taken to repay debt increases for all borrowers following a waiver, after controlling for loan volume, landholdings, and output of the farmers and all other relevant factors. Interestingly, the effects are the most negative for the group that do not benefit at all. Expectations of similar debt relief in future coupled with extensions on loan repayment granted by bankers who find debt recovery difficult drive our results that suggest ex post inefficiency in the credit market. The group that did not have overdue loans in the past use extensions based on their good credit history to keep their loans outstanding the longest in the post-waiver period. Further, rationally anticipating adverse borrower behavior, the lending institutions ration credit, generating ex ante inefficiency as well. Ironically, access to finance for poor households declines following unconditional debt relief.

For our empirical investigations we have used loan accounts data for a large sample of rural borrowers before and after a massive nation-wide debt relief program undertaken by the Indian government in 2008. One of the largest such programs in history, the Debt Relief and Debt Waiver Scheme for Small and Marginal Farmers (2008) ultimately covered about 36 million farmers. The total cost of the program amounted to about $1.3 \%$ of India's GDP at the time.

Our findings in this paper have documented a pervasive deterioration of the borrowing culture due to the debt waiver program. The resulting ex post and ex ante inefficiencies in the rural credit market must have been substantial. However, the program involved other and possibly more substantial costs for the economy. It represented a massive transfer to the agricultural sector at the expense of other activities and services of the government. It is beyond the scope of the present paper to attempt to estimate the cost implications for the 
other sectors in a general equilibrium framework. However, those costs too must have been substantial. We do not find records suggesting that those other costs, and their implications, were extensively discussed in policy circles. The policy makers who undertake a massive policy initiative of this kind should recognize, and worry about, both direct and indirect costs of the initiative.

Following the global financial crisis of 2008, many sizable debt relief programs have taken place across the globe in recent years. However, we find no study in the existing literature that either models the effects of a debt relief program on the post-waiver loan repayment behavior of strategic borrowers, or empirically documents the effects. We hope that the findings in the present study are useful in filling in a critical gap in the current state of knowledge.

At the end, we would like to reiterate an observation we have made in the introduction of this paper. Our findings do not suggest that all government interventions in private debt markets have negative consequences. There are situations where agricultural debt relief is necessary and improves efficiency, such as debt relief following a severe drought. As we have stated above, anticipation of more debt relief programs in future coupled with extensions on debt repayment beyond the due date permitted by the bankers explain our findings. If the two contributory factors are controlled appropriately, adverse efficiency implications of a debt relief program will be minimized. However, controlling them is no mean task. It will require political discipline backed by clear articulation of a policy of interventions only in poor states of nature with a view to limiting undue expectations. It will also require better enforcement of debt contracts, enabling bank loan officers to handle prospects of bad debt with more confidence and less risk to their performance records. In other words, the task will require significant political and structural reform. 


\section{Appendix}

Some statistics regarding annual rainfall and agricultural production in India 2005 - 2012 (Source: IndiaStats.com)

Table A1. Annual rainfall

\begin{tabular}{|l|r|r|}
\hline Year & $\begin{array}{c}\text { Percentage of sub-divisions } \\
\text { with deficient rainfall }\end{array}$ & $\begin{array}{c}\text { Actual rainfall as percentage } \\
\text { of normal rainfall }\end{array}$ \\
\hline 2005 & 4 & 99 \\
\hline 2006 & 10 & 99 \\
\hline 2007 & 5 & 106 \\
\hline 2008 & 3 & 98 \\
\hline 2009 & 22 & 78 \\
\hline 2010 & 5 & 102 \\
\hline 2011 & 3 & 101 \\
\hline 2012 & 13 & 92 \\
\hline Average & 8 & 97 \\
\hline
\end{tabular}

Table A2: Agricultural production

\begin{tabular}{|l|c|c|c|}
\hline \multirow{2}{*}{ Year } & Area under cultivation & Production & Yield \\
\cline { 2 - 4 } & (million hectares) & (million tonnes) & (Kg/ hectare) \\
\hline $\begin{array}{l}2005- \\
06\end{array}$ & 121.6 & 208.6 & 1715 \\
\hline $\begin{array}{l}2006- \\
07\end{array}$ & 123.7 & 217.3 & 1756 \\
\hline $\begin{array}{l}2007- \\
08\end{array}$ & 124.1 & 230.8 & 1860 \\
\hline $\begin{array}{l}2008- \\
09\end{array}$ & 122.8 & 234.5 & 1909 \\
\hline $\begin{array}{l}2009- \\
10\end{array}$ & 121.3 & 218.1 & 1798 \\
\hline $2010-$ & 126.7 & 244.5 & 1930 \\
11 & 125 & 257.4 & 2059 \\
\hline $2011-$ & 123.6 & 230.2 & 1861 \\
12 & & & \\
\hline Average & & & \\
\hline
\end{tabular}




\section{References}

Allen F., J. Qian, and M. Qian (2005), "Law, Finance, and Economic Growth in China", Journal of Financial Economics.

Allen F., R. Chakrabarti, S. De, J. Qian, and M. Qian (2012), "Financing Firms in India”, Journal of Financial Intermediation.

Banerjee, A. (2000), "The Two Poverties," Nordic Journal of Political Economy.

Banerjee, A. and E. Duflo, (2008), "Do Firms Want to Borrow More? Testing Credit Constraints Using a Natural Experiment", MIT working paper.

Banerjee, A. and A. Newman (1993), "Occupational Choice and the Process of Development," The Journal of Political Economy.

Bolton, P. and H. Rosenthal (2002), "Political Intervention in Debt Contracts," Journal of Political Economy.

Cole, S. A. (2009), "Fixing Market Failures or Fixing Elections? Elections, Banks and Agricultural Lending in India," American Economic Journal: Applied Economics.

Cole, S.A., A. Healy and E. Werker (2012). "Do Voters Demand Responsive Governments? Evidence from Indian Disaster Relief." Journal of Development Economics.

Deschênes, O. and M. Greenstone "Climate Change, Mortality, and Adaptation: Evidence from Annual Fluctuations in Weather in the US," American Economic Journal: Applied Economics.

Dinc, S. (2005), "Politicians and Banks: Political Influences on Government-Owned Banks in Emerging Markets", Journal of Financial Economics.

Ghosh, P., D. Mookherjee, and D. Ray (2000), “Credit Rationing in Developing Countries: An

Overview of the Theory," D. Mookherjee and D. Ray (eds) A Reader in Development Economics, Guiso, L., P. Sapienza and L. Zingales, (2013), "The Determinants of Attitudes toward Strategic Default on Mortgages", Journal of Finance.

Jensen, M. and W. Meckling (1976), "Theory of the firm: Managerial behavior, agency costs and ownership structure," Journal of Financial Economics.

Khwaja, A. I. and A. Mian (2005), "Do Lenders Favor Politically Connected Firms? Rent Provision in an Emerging Financial Market*," Quarterly Journal of Economics.

Kroszner RS (1998), " It is better to forgive than receive", Quarterly Journal of Economics

La Porta, R., F. Lopez De-Silanes, and A. Shleifer (2002), "Government Ownership of Banks,"

The Journal of Finance. 
Kanz, M. (2011), "What does Debt Relief do for Development? Evidence from a Large-Scale Policy Experiment", World Bank Working Paper

Mookherjee, D. and D. Ray (2003), "Persistent Inequality," Review of Economic Studies.

Myers, S. (1977), "Determinants of Corporate Borrowing," Journal of Financial Economics. 
Graph 1: Agricultural production and agriculture NPAs of public sector banks during 2005 - 2011

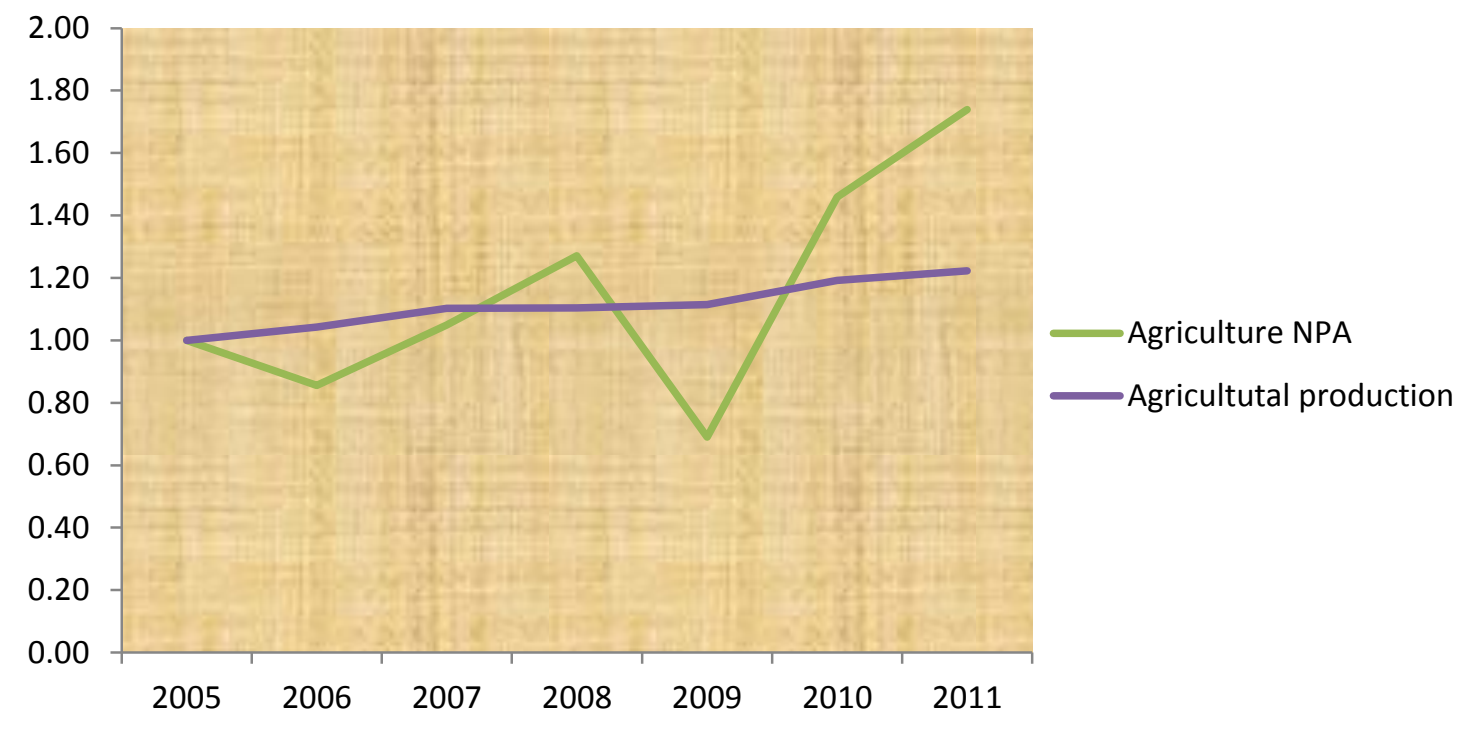

Graph 2: Agricultural and total NPAs of public sector banks during 2005 - 2011

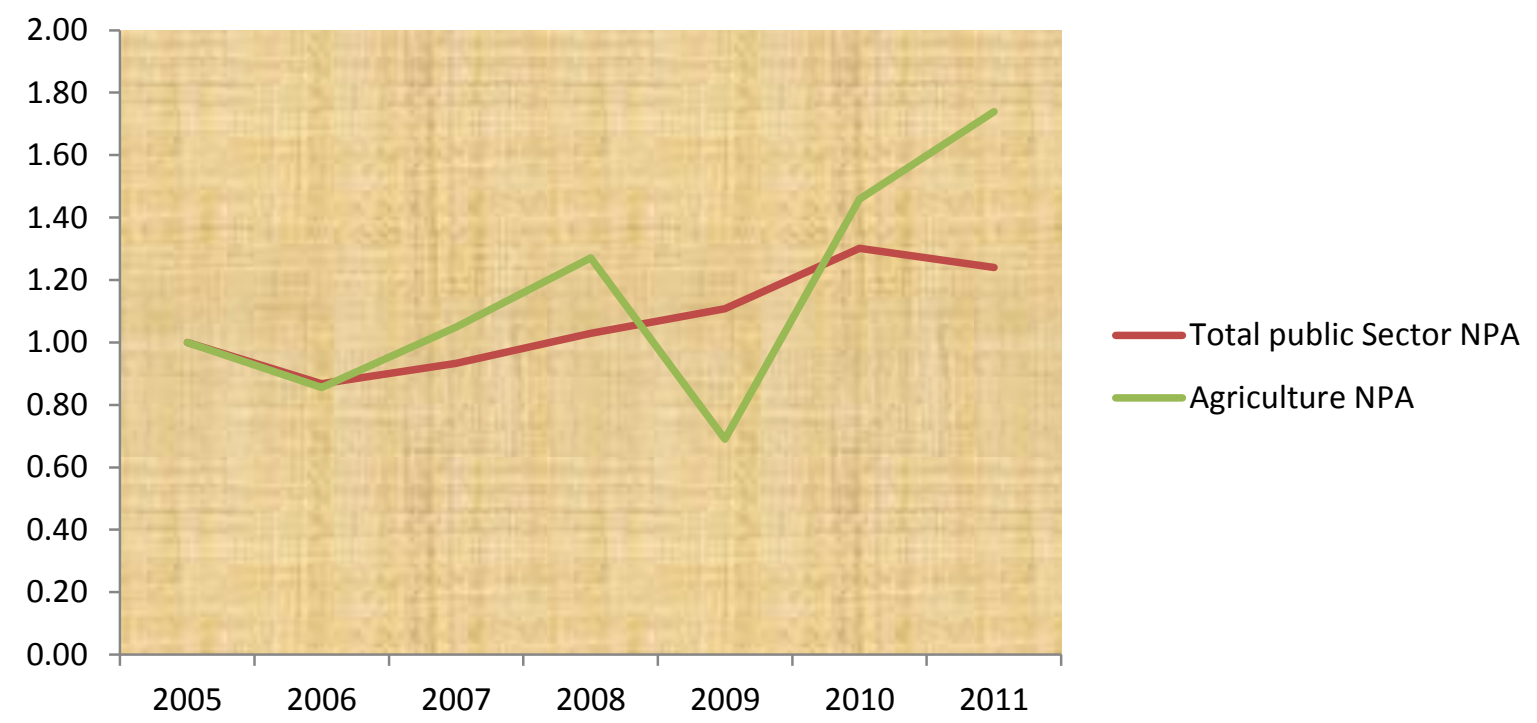

2005 NPA and Production numbers are standardized at 1. NPA amounts are in rupees crores. Source : www.rbi.org.in 
Exhibit 1: Within Group Comparison: Days outstanding in pre and post-waiver periods

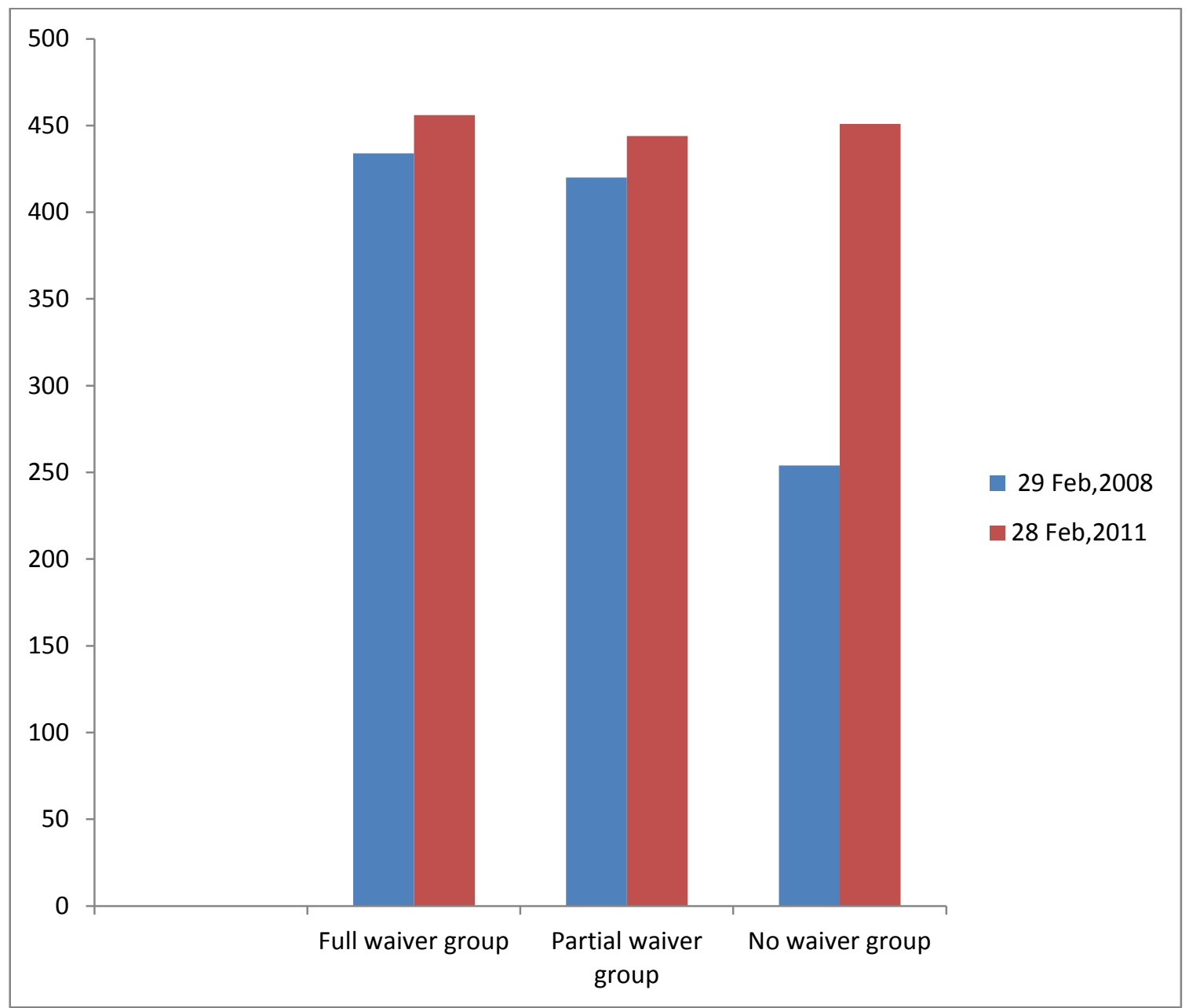




\section{Table 1: Summary Statistics}

The table reports key summary statistics of the loan accounts. Farmers in the sample are divided into three groups. Defaulting Farmers who have pledged not more than 2 hectares of land belong to full waiver group. Defaulting Farmers who have pledged more than 2 hectares of land belong to partial waiver group and the non defaulters belong to No waiver Group. We report Number of farmers belonging to each group. We also report the average, median, quartile1 and quartile 3 for number days the last drawn loan is outstanding as on 29th February 2008, average amount of loan outstanding and landholding. Landholding details are available only for full waiver and partial waiver group. The data is from loan account level information obtained from a public sector bank. The data covers the period from 2005-2006 to 2010-2011.

\begin{tabular}{|l|c|c|c|c|}
\hline Variables & Full waiver & Partial Waiver & No Waiver & $\begin{array}{c}\text { Full } \\
\text { Sample }\end{array}$ \\
\hline Number of farmers & 8064 & 2209 & 2372 & 12645 \\
\hline Land holding & & & & \\
\hline Mean & 0.99 & 5.66 & & 2.37 \\
\hline Median & 1.00 & 3.11 & & 1.25 \\
\hline Q1 & 0.54 & 2.45 & & 0.67 \\
\hline Q3 & 1.47 & 4.25 & & 2.13 \\
\hline Loan Outstanding (days as of Feb 29,2008) & & & & \\
\hline Mean & 434 & 419 & 254 & 373 \\
\hline Median & 443 & 405 & 251 & 366 \\
\hline Q1 & 345 & 318 & 186 & 238 \\
\hline Q3 & 556 & 552 & 331 & 500 \\
\hline Average Loan (Oct 2005 - Feb 2008) & & & & \\
\hline Mean & 23618 & 48746 & 26051 & 28458 \\
\hline Median & 18233 & 40800 & 21792 & 22000 \\
\hline Q1 & 10000 & 26000 & 13584 & 11822 \\
\hline Q3 & 30000 & 51090 & 35000 & 37532 \\
\hline Total Number of Loans as of Feb 29, 2008 & 8166 & 2565 & 5143 & 15874 \\
\hline Total Number of Loans as of Feb 29, 2011 & 12585 & 3097 & 3717 & 19399 \\
\hline
\end{tabular}




\section{Table 2: Within Group Comparison: Days outstanding in pre and post-waiver periods Univariate tests}

The table reports the number of days the last loan is outstanding before and after the loan waiver program announcement (February 29, 2011). The outstanding days before is calculated as of 29th February, 2008 and after as of 28th February, 2011. The results for all three groups of farmer (full waiver, no waiver and partial waiver) are reported. We also report the results of difference in means test for each group between days outstanding before and after.

\begin{tabular}{|l|c|c|c|}
\hline Number of days loan outstanding & 29 Feb,2008 & 28 Feb,2011 & $\begin{array}{c}\text { Mean difference } \\
\text { T-stats }\end{array}$ \\
\hline Full waiver group & & & \\
\hline Partial waiver group & 434 & 456 & $-5.9^{* * *}$ \\
\hline & 419 & 444 & $-3.7^{* * *}$ \\
\hline No waiver group & & & $-45.6^{* * *}$ \\
\hline
\end{tabular}

$*, * *$, and $* * *$ indicate significance at the $10 \%, 5 \%$ and $1 \%$ levels respectively 


\section{Table 3A: Within Group Comparison: Days outstanding in pre and post-waiver periods Multivariate tests based on all loans before and after the waiver}

The table reports the regression results of the following equation for our sample of farmers in 4 districts of Andhra Pradesh, India, during 2005-2011

Days $_{i j t}=\alpha+v_{b}+\delta$ PostO $+B_{1}$ Loan $_{i j t}+B_{2}$ Land $_{i t}+B_{3}$ Production $_{d t}+B_{4}$ Rain $_{d t}+B_{5}$ Credit $_{d t}+B_{6}$ Inflation $_{t}+\varepsilon_{i t}$

The dependent variable Days $s_{i j t}$ is the number of days loan $\mathrm{j}$ taken by farmer $\mathrm{i}$ remains outstanding in the pre waiver period $(\mathrm{t}=0)$ and post waiver period $(\mathrm{t}=1)$. The independent variable of interest, Post08, takes value 1 if the loan is taken in the post-waiver period; 0 otherwise. Loan $_{i j t}$ and Land $_{i t}$ are farmer-specific control variables. Loan ${ }_{i j t}$ represents the amount of loan $\mathrm{j}$ taken by farmer $\mathrm{i}$ in the pre-waiver period $(\mathrm{t}=$ 0 ) and in the post-waiver period $(\mathrm{t}=1)$. Land $_{i t}$ is the landholding of farmer $\mathrm{i}$ in the two periods. Production $_{d t}$ Rain $_{d t}$ and Credit $d t$ are district-specific control variables and refer to the district $d$ that farmer i resides in. They represent the total food grains production, rainfall, and credit flow in the district in the year loan $\mathrm{j}$ is taken. Inflation $_{t}$ indicates inflation rates based on monthly consumer price index for agricultural laborers (CPIAL) in the pre-waiver period $(t=0)$ and in the post-waiver period $(t=$ 1). Branch fixed effects $v_{b}$ are included in all specifications, and standard errors are cluster-adjusted at the branch level.

The table reports within group variation for full waiver, partial waiver and no waiver groups separately, statistics are reported in brackets.

\begin{tabular}{|l|c|c|c|}
\hline & Full Waiver & Partial Waiver & No waiver \\
\hline VARIABLES & Days & Days & Days \\
\hline Post08 & & & $352.9^{* * *}$ \\
\hline Loan & $130.9^{*}$ & 137.1 & {$[3.4]$} \\
\hline & {$[1.8]$} & {$[1.5]$} & -.0 .0 \\
\hline Land & -.0 .0 & -.0 .0 & {$[-1.1]$} \\
\hline & {$[-1.0]$} & {$[-1.0]$} & \\
\hline Production & $-21.4^{*}$ & 0.0 & \\
\hline & {$[-1.8]$} & {$[0.7]$} & 0.0 \\
\hline Rain & -0.1 & $-0.1 * *$ & {$[0.2]$} \\
\hline Credit & {$[-1.6]$} & {$[-2.2]$} & YES \\
\hline Inflation & YES & YES & YES \\
\hline Branch FE & YES & YES & YES \\
\hline Observations & YES & YES & YES \\
\hline Number of accounts & YES & YES & 8,845 \\
\hline R & 13,087 & 5,491 & 2,360 \\
\hline
\end{tabular}




\section{Table 3B: Within Group Comparison: Days outstanding in pre and post-waiver periods Multivariate tests Based on the last loan before waiver and all loans after waiver}

The table reports the regression results of the following equation for our sample of farmers in 4 districts of Andhra Pradesh, India, during 2005-2011

Days $_{i j t}=\alpha+v_{b}+\delta$ PostO $+B_{1}$ Loan $_{i j t}+B_{2}$ Land $_{i t}+B_{3}$ Production $_{d t}+B_{4}$ Rain $_{d t}+B_{5}$ Credit $_{d t}+$ B $_{6}$ Inflation $_{t}+\varepsilon_{i t}$

The dependent variable Days $_{i j t}$ is the number of days loan $\mathrm{j}$ taken by farmer $\mathrm{i}$ remains outstanding in the pre waiver period $(\mathrm{t}=0)$ and post waiver period $(\mathrm{t}=1)$. The independent variable of interest, Post08, takes value 1 if the loan is taken in the post-waiver period; 0 otherwise. Loan $_{i j t}$ and Land $_{i t}$ are farmer-specific control variables. Loan $_{i j t}$ represents the amount of loan $\mathrm{j}$ taken by farmer $\mathrm{i}$ in the pre-waiver period $(\mathrm{t}=$ 0 ) and in the post-waiver period $(\mathrm{t}=1)$. Land $_{i t}$ is the landholding of farmer $\mathrm{i}$ in the two periods. Production $_{d t}$ Rain $_{d t}$ and Credit $d t$ are district-specific control variables and refer to the district $d$ that farmer i resides in. They represent the total food grains production, rainfall, and credit flow in the district in the year loan $\mathrm{j}$ is taken. Inflation $_{t}$ indicates inflation rates based on monthly consumer price index for agricultural laborers (CPIAL) in the pre-waiver period $(t=0)$ and in the post-waiver period $(t=$ 1). Branch fixed effects $v_{b}$ are included in all specifications, and standard errors are cluster-adjusted at the branch level.

The table reports within group variation for full waiver, partial waiver and no waiver groups separately. T-statistics are reported in brackets,

\begin{tabular}{|l|c|c|c|}
\hline & Full waiver & Partial waiver & No waiver \\
\hline VARIABLES & Days & Days & Days \\
\hline Post08 & & & $354.0^{* * *}$ \\
\hline & 83.4 & 103.5 & {$[3.7]$} \\
\hline Loan & {$[1.0]$} & {$[1.2]$} & -0.0 \\
\hline & -0.0 & -0.0 & {$[-.74]$} \\
\hline Land & {$[-1.12]$} & {$[-.12]$} & \\
\hline & -11.6 & $0.0 * * *$ & -0.0 \\
\hline Production & {$[-1.0]$} & {$[7.0]$} & {$[-0.0]$} \\
\hline & -0.2 & $-0.2 *$ & \\
\hline Land & {$[-1.5]$} & $0.0 * * *$ & Yes \\
\hline & -11.6 & {$[7.0]$} & Yes \\
\hline Rain & {$[-1.0]$} & Yes & Yes \\
\hline Credit & Yes & Yes & Yes \\
\hline Inflation & Yes & Yes & 6,034 \\
\hline Branch FE & Yes & Yes & 2,360 \\
\hline Observations & Yes & 4,793 & 0.4 \\
\hline Number of Accounts & 11,639 & 2,145 & 0.18 \\
\hline$R^{2}$ & 4,913 & & \\
\hline
\end{tabular}




\section{Table 3C: Within Group Comparison: Days outstanding in pre and post-waiver periods Multivariate tests Based on the last loan before waiver and the first loan after waiver}

The table reports the regression results of the following equation for our sample of farmers in 4 districts of Andhra Pradesh, India, during 2005-2011

Days $_{i j t}=\alpha+v_{b}+\delta$ PostO $+B_{1}$ Loan $_{i j t}+B_{2}$ Land $_{i t}+B_{3}$ Production $_{d t}+B_{4}$ Rain $_{d t}+B_{5}$ Credit $_{d t}+B_{6}$ Inflation $_{t}+\varepsilon_{i t}$

The dependent variable Days $s_{i j t}$ is the number of days loan $\mathrm{j}$ taken by farmer $\mathrm{i}$ remains outstanding in the pre waiver period $(\mathrm{t}=0)$ and post waiver period $(\mathrm{t}=1)$. The independent variable of interest, Post08, takes value 1 if the loan is taken in the post-waiver period; 0 otherwise. Loan $_{i j t}$ and Land $_{i t}$ are farmer-specific control variables. Loan $_{i j t}$ represents the amount of loan $\mathrm{j}$ taken by farmer $\mathrm{i}$ in the pre-waiver period $(\mathrm{t}=$ 0 ) and in the post-waiver period $(\mathrm{t}=1)$. Land $_{i t}$ is the landholding of farmer $\mathrm{i}$ in the two periods. Production $_{d t}$ Rain $_{d t}$ and Credit $d t$ are district-specific control variables and refer to the district $d$ that farmer i resides in. They represent the total food grains production, rainfall, and credit flow in the district in the year loan $\mathrm{j}$ is taken. Inflation $_{t}$ indicates inflation rates based on monthly consumer price index for agricultural laborers (CPIAL) in the pre-waiver period $(t=0)$ and in the post-waiver period $(t=$ 1). Branch fixed effects $v_{b}$ are included in all specifications, and standard errors are cluster-adjusted at the branch level.

The table reports within group variation for full waiver, partial waiver and no waiver groups separately. T-statistics are reported in brackets.

\begin{tabular}{|l|c|c|c|}
\hline & Full Waiver & Partial Waiver & No waiver \\
\hline VARIABLES & Days & Days & Days \\
\hline Post08 & & & $397.5^{* * *}$ \\
\hline & $72.0^{* *}$ & $214.9 * * *$ & {$[5.0]$} \\
\hline Loan & {$[2.1]$} & {$[7.5]$} & 0.0 \\
\hline & 0.0 & 0.0 & {$[0.67]$} \\
\hline Land & {$[1.1]$} & {$[1.2]$} & \\
\hline & -15.7 & $0.0 * * *$ & 0.1 \\
\hline Production & {$[-0.8]$} & {$[3.5]$} & {$[0.3]$} \\
\hline & $-0.5 * * *$ & $-0.3 * * *$ & Yes \\
\hline Rain & {$[-8.4]$} & {$[-5.1]$} & Yes \\
\hline Credit & Yes & Yes & Yes \\
\hline Inflation & Yes & Yes & Yes \\
\hline BranchFE & Yes & Yes & 4,569 \\
\hline Observations & Yes & Yes & 2,360 \\
\hline Number of Accounts & 8,524 & 3,586 & 0.45 \\
\hline$R^{2}$ & 4,913 & 2,145 & 0.21 \\
\hline
\end{tabular}




\section{Table 3D: Within Group Comparison: Days outstanding in pre and post-waiver periods Multivariate tests Based on last loan before waiver and last loan after waiver}

The table reports the regression results of the following equation for our sample of farmers in 4 districts of Andhra Pradesh, India, during 2005-2011

Days $_{i j t}=\alpha+v_{b}+\delta$ PostO $+B_{1}$ Loan $_{i j t}+B_{2}$ Land $_{i t}+B_{3}$ Production $_{d t}+B_{4}$ Rain $_{d t}+B_{5}$ Credit $_{d t}+$ B $_{6}$ Inflation $_{t}+\varepsilon_{i t}$

The dependent variable Days $_{i j t}$ is the number of days loan $\mathrm{j}$ taken by farmer $\mathrm{i}$ remains outstanding in the pre waiver period $(\mathrm{t}=0)$ and post waiver period $(\mathrm{t}=1)$. The independent variable of interest, Post08, takes value 1 if the loan is taken in the post-waiver period; 0 otherwise. Loan $_{i j t}$ and Land $_{i t}$ are farmer-specific control variables. Loan $_{i j t}$ represents the amount of loan $\mathrm{j}$ taken by farmer $\mathrm{i}$ in the pre-waiver period $(\mathrm{t}=$ 0 ) and in the post-waiver period $(\mathrm{t}=1)$. Land $_{i t}$ is the landholding of farmer $\mathrm{i}$ in the two periods. Production $_{d t}$ Rain $_{d t}$ and Credit $d t$ are district-specific control variables and refer to the district $d$ that farmer i resides in. They represent the total food grains production, rainfall, and credit flow in the district in the year loan $\mathrm{j}$ is taken. Inflation ${ }_{t}$ indicates inflation rates based on monthly consumer price index for agricultural laborers (CPIAL) in the pre-waiver period $(t=0)$ and in the post-waiver period $(t=$ 1). Branch fixed effects $v_{b}$ are included in all specifications, and standard errors are cluster-adjusted at the branch level. The table reports within group variation for full waiver, partial waiver and no waiver groups separately. T-statistics are reported in brackets.

\begin{tabular}{|l|c|c|c|}
\hline & Full waiver & Partial waiver & No Waiver \\
\hline VARIABLES & Days & Days & Days \\
\hline Post08 & & & $172.2^{* * *}$ \\
\hline Loan & -84.0 & 52.0 & {$[4.0]$} \\
\hline & {$[-1.3]$} & {$[1.2]$} & $0.0^{* *}$ \\
\hline Land & -0.0 & -0.0 & {$[2.2]$} \\
\hline & {$[-.68]$} & {$[-0.04]$} & \\
\hline Production & 10.6 & $-.03^{* *}$ & \\
\hline & {$[-.58]$} & {$[-1.83]$} & 0.2 \\
\hline Rain & $-0.4^{* * *}$ & $-0.3^{* * *}$ & {$[1.2]$} \\
\hline Credit & {$[-5.7]$} & {$[-5.8]$} & Yes \\
\hline Inflation & Yes & Yes & Yes \\
\hline Branch FE & Yes & Yes & Yes \\
\hline Observations & Yes & Yes & Yes \\
\hline Number of Accounts & Yes & Yes & 3,798 \\
\hline R $^{2}$ & 6,982 & 3,018 & 2,342 \\
\hline
\end{tabular}


Table 4: Between group comparison:

\section{Days outstanding in pre and post-waiver periods}

The table reports the regression results of the following equation for our sample of farmers in 4 districts of Andhra Pradesh, India, during 2005-2011:

Days $_{i t}=\alpha+v_{b}+\delta_{1}$ Post08 $+\delta_{2}$ Fullwaiver $+\delta_{3}$ Partialwaiver $+\delta_{4}$ Post08*Fullwaiver $+\delta_{5}$ Post08*Partial

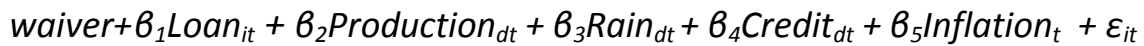

The dependent variable Days $_{i t}$ is the number days the a loan is outstanding as on February 29, $2008(t=0)$ and February 28, $2011(t=1)$ for farmer $i$. The independent variable, Post08, takes value 1 if the loan was taken in the post-waiver period; 0 otherwise. Fullwaiver (Partialwaiver) takes a value of 1 if the farmer belongs to the full-waiver (partial-waiver) group; 0 otherwise. Loan $_{i j t}$ represents the amount of loan $\mathrm{j}$ taken by farmer $\mathrm{i}$ in the pre-waiver period $(\mathrm{t}=0)$ and in the post-waiver period $(\mathrm{t}=1)$. Production $_{d t}$ Rain $_{d t}$ and Credit $d t$ are district-specific control variables and refer to the district $d$ that farmer i resides in. They represent the total food grains production, rainfall, and credit flow in the district in the year loan $\mathrm{j}$ is taken. Inflation $_{t}$ indicates inflation rates based on monthly consumer price index for agricultural laborers $(C P I A L)$ in the pre-waiver period $(t=0)$ and in the post-waiver period $(t=$ 1). Branch fixed effects $v_{b}$ are included in all specifications, and standard errors are cluster-adjusted at the branch level. Column 1 compares all loans before waiver with all loans after waiver. Column 2 compares the last loan before waiver with all loans after waiver. Column 3 compares the last loan before waiver with the first loan after waiver. Column 4 compares the last loan before waiver with the last loan after waiver in our sample period. T-statics are reported in brackets.

\begin{tabular}{|l|c|c|c|c|}
\hline & $(1)$ & $(2)$ & $(3)$ & $(4)$ \\
\hline VARIABLES & Days & Days & Days & Days \\
\hline Post08 & & & & \\
\hline & $278.3^{* * *}$ & $306.9^{* * *}$ & $384.2^{* * *}$ & $228.1^{* * *}$ \\
\hline Fullwaiver & {$[5.4]$} & {$[7.2]$} & {$[7.0]$} & {$[2.8]$} \\
\hline & $160.1^{* * *}$ & $241.5^{* * *}$ & $186.4^{* * *}$ & $174.7^{* * *}$ \\
\hline Partialwaiver & {$[6.8]$} & {$[6.3]$} & {$[3.5]$} & {$[4.5]$} \\
\hline & $145.2^{* * *}$ & $233.7^{* * *}$ & $180.1^{* * *}$ & $172.0^{* * *}$ \\
\hline FullWaiver*Post08 & {$[5.1]$} & {$[5.5]$} & {$[3.0]$} & {$[4.0]$} \\
\hline & $-184.7^{* * *}$ & $-259.0^{* * *}$ & $-266.5^{* * *}$ & $-245.3^{* * *}$ \\
\hline Partialwaiver*Post08 & {$[-3.6]$} & {$[-5.6]$} & {$[-7.2]$} & {$[-6.7]$} \\
\hline & $-165.6^{* * *}$ & $-248.7^{* * *}$ & $-243.6^{* * *}$ & $-208.4^{* * *}$ \\
\hline Loan & {$[-3.0]$} & {$[-4.8]$} & {$[-6.3]$} & {$[-4.4]$} \\
\hline & -0.0 & -0.0 & $0.0 * * *$ & $0.0 * * *$ \\
\hline Production & {$[-0.55]$} & {$[-0.56]$} & {$[5.12]$} & {$[2.6]$} \\
\hline & -0.0 & -0.1 & $-0.3^{*}$ & $-0.2^{*}$ \\
\hline Rain & {$[-0.6]$} & {$[-0.7]$} & {$[-1.9]$} & {$[-1.7]$} \\
\hline Credit & Yes & Yes & Yes & Yes \\
\hline Inflation & Yes & Yes & Yes & Yes \\
\hline Branch FE & Yes & Yes & Yes & Yes \\
\hline Observations & Yes & Yes & Yes & Yes \\
\hline Number of Accounts & 35,253 & 29,795 & 22,061 & 18,214 \\
\hline$R^{2}$ & 12,630 & 12,630 & 12,630 & 11,291 \\
\hline & 0.15 & 0.23 & 0.14 & 0.37 \\
\hline
\end{tabular}


Table 5: Between group comparison:

Probability of default pre and post waiver

The table reports the regression results of the following linear probability model for our sample of farmers in 4 districts of Andhra Pradesh, India, during 2005-2011:

Default $t_{i j t}=\alpha+v_{b}+\delta_{1}$ Post08 $+\delta_{2}$ Fullwaiver $+\delta_{3}$ Partialwaiver $+\delta_{4}$ Post08*Fullwaiver $+\delta_{5}$ Post08*Partial waiver $B_{1}$ Loan $_{i t}+B_{2}$ Production $_{d t}+B_{3}$ Rain $_{d t}+B_{4}$ Credit $_{d t}+B_{5}$ Inflation $_{t}+\varepsilon_{i t}$

The dependent variable Defaul $t_{i j t}$ takes a value of 1 if a loan i of farmer $j$ remains outstanding for more than 365 days. The independent variable, Post08, takes value 1 if the loan was taken in the post-waiver period; 0 otherwise. Fullwaiver (Partialwaiver) takes a value of 1 if the farmer belongs to the full-waiver (partial-waiver) group; 0 otherwise. Loan $_{i j t}$ represents the amount of loan $j$ taken by farmer $i$ in the prewaiver period $(\mathrm{t}=0)$ and in the post-waiver period $(\mathrm{t}=1)$. Production ${ }_{d t}$ Rain $_{d t}$ and Credit $_{d t}$ are districtspecific control variables and refer to the district $d$ that farmer i resides in. They represent the total food grains production, rainfall, and credit flow in the district in the year loan $\mathrm{j}$ is taken. Inflation $_{t}$ indicates inflation rates based on monthly consumer price index for agricultural laborers (CPIAL) in the pre-waiver period $(t=0)$ and in the post-waiver period $(t=1)$. Branch fixed effects $v_{b}$ are included in all specifications, and standard errors are cluster-adjusted at the branch level. Column 1 compares all loans before waiver with all loans after waiver. Column 2 compares the last loan before waiver with all loans after waiver. Column 3 compares the last loan before waiver with the first loan after waiver. Column 4 compares the last loan before waiver with the last loan after waiver in our sample period. T-statistics are reported in brackets.

\begin{tabular}{|l|c|c|c|c|}
\hline & $(1)$ & $(2)$ & $(3)$ & $(4)$ \\
\hline VARIABLES & Default & Default & Default & Default \\
\hline & & & & \\
\hline Post08 & $0.30^{* * *}$ & $0.43^{* * *}$ & $0.58^{* * *}$ & $0.39^{* * *}$ \\
\hline Fullwaiver & {$[4.2]$} & {$[7.6]$} & {$[7.3]$} & {$[6.7]$} \\
\hline & $0.53^{* * *}$ & $0.80^{* * *}$ & $0.76^{* * *}$ & $0.72^{* * *}$ \\
\hline Partialwaiver & {$[11.0]$} & {$[14.9]$} & {$[8.0]$} & {$[9.9]$} \\
\hline & $0.49^{* * *}$ & $0.78^{* * *}$ & $0.76^{* * *}$ & $0.75^{* * *}$ \\
\hline Fullwaiver*Post08 & {$[8.9]$} & {$[13.5]$} & {$[6.6]$} & {$[8.5]$} \\
\hline & $-0.50^{* * *}$ & $-0.75^{* * *}$ & $-0.79^{* * *}$ & $-0.70^{* * *}$ \\
\hline Partialwaiver*Post08 & {$[-6.3]$} & {$[-10.9]$} & {$[-16.1]$} & {$[-13.6]$} \\
\hline & $-0.50^{* * *}$ & $-0.76^{* * *}$ & $-0.78^{* * *}$ & $-0.67^{* * *}$ \\
\hline Loan & {$[-6.8]$} & {$[-14.1]$} & {$[-14.5]$} & {$[-9.7]$} \\
\hline & -.0 .0 & -.0 .0 & -.0 .0 & -.0 .0 \\
\hline Production & {$[-.67]$} & {$[-.83]$} & {$[-.45]$} & {$[-1.12]$} \\
\hline Rain & Yes & Yes & Yes & Yes \\
\hline Credit & Yes & Yes & Yes & Yes \\
\hline Inflation & Yes & Yes & Yes & Yes \\
\hline Branch FE & Yes & Yes & Yes & Yes \\
\hline Observations & Yes & Yes & Yes & Yes \\
\hline Number of Accounts & 35,253 & 29,795 & 22,061 & 18,214 \\
\hline $\mathrm{R}^{2}$ & 12,630 & 12,630 & 12,630 & 11,291 \\
\hline & 0.19 & 0.24 & 0.29 & 0.41 \\
\hline
\end{tabular}




\section{Table 6: Between group comparison for farmers with similar average loans: Days outstanding in pre- and post-waiver periods (based on all loans before and after waiver)}

The table reports the regression results of the following equation for our sample of farmers in 4 districts of Andhra Pradesh, India, during 2005-2011:

Days $_{i t}=\alpha+v_{b}+\delta_{1}$ Post08 $+\delta_{2}$ Fullwaiver $+\delta_{3}$ Partialwaiver $+\delta_{4}$ Post08*Fullwaiver $+\delta_{5}$ Post08*Partial

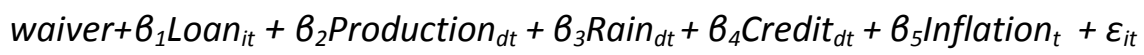

The dependent variable Days $_{i t}$ is the number days the a loan is outstanding as on February 29, $2008(\mathrm{t}=$ 0 ) and February 28, $2011(\mathrm{t}=1)$ for farmer $i$. The independent variable, Post08, takes value 1 if the loan was taken in the post-waiver period; 0 otherwise. Fullwaiver (Partialwaiver) takes a value of 1 if the farmer belongs to the full-waiver (partial-waiver) group; 0 otherwise. Loan $_{i j t}$ represents the amount of loan $\mathrm{j}$ taken by farmer $\mathrm{i}$ in the pre-waiver period $(\mathrm{t}=0)$ and in the post-waiver period $(\mathrm{t}=1)$. Production $_{d t}$ Rain $_{d t}$ and Credit $d t$ are district-specific control variables and refer to the district $d$ that farmer i resides in. They represent the total food grains production, rainfall, and credit flow in the district in the year loan $\mathrm{j}$ is taken. Inflation ${ }_{t}$ indicates inflation rates based on monthly consumer price index for agricultural laborers (CPIAL) in the pre-waiver period $(t=0)$ and in the post-waiver period $(t=$ $1)$. Branch fixed effects $v_{b}$ are included in all specifications, and standard errors are cluster-adjusted at the branch level. T-statistics are reported in brackets.

The reported results are for four separate groups:

Group 1: average loan amount up to INR 11,266 (quartile1 of average loan amount in pre-waver period) Group 2: average loan amount more than INR 11,266 but not exceeding 21,000 (median loan amount) Group 3: average loan amount more than INR 21,000 but not exceeding 35,000 (quartile 3) Group 4: average loan amount exceeding INR 35,000

\begin{tabular}{|l|c|c|c|c|}
\hline & Group 1 & Group 2 & Group 3 & Group 4 \\
\hline VARIABLES & Days & Days & Days & Days \\
\hline Post08 & $323.8^{* * *}$ & $329.0^{* * *}$ & $263.6^{* * *}$ & $235.9^{* * *}$ \\
\hline & {$[8.9]$} & {$[6.1]$} & {$[4.0]$} & {$[3.8]$} \\
\hline Fullwaiver & $180.3^{* * *}$ & $179.8^{* * *}$ & $151.2^{* * *}$ & $91.2^{* * *}$ \\
\hline & {$[6.9]$} & {$[6.4]$} & {$[6.6]$} & {$[3.2]$} \\
\hline Partialwaiver & $161.7^{* * *}$ & $126.0^{* * *}$ & $127.0^{* * *}$ & $142.4^{* * *}$ \\
\hline & {$[6.0]$} & {$[3.1]$} & {$[4.4]$} & {$[8.8]$} \\
\hline Fullwaiver*Post08 & $-231.0^{* * *}$ & $-233.8^{* * *}$ & $-176.9^{* * *}$ & $-93.4^{* *}$ \\
\hline & {$[-4.8]$} & {$[-4.1]$} & {$[-2.9]$} & {$[-2.4]$} \\
\hline Partialwaiver*Post08 & $-167.1^{* * *}$ & $-113.1^{*}$ & $-142.4^{* *}$ & $-133.6^{* * *}$ \\
\hline & {$[-3.2]$} & {$[-1.7]$} & {$[-2.1]$} & {$[-3.2]$} \\
\hline Loan & -0.0 & -0.0 & -0.0 & 0.0 \\
\hline & {$[-0.3]$} & {$[-1.0]$} & {$[-0.68]$} & {$[0.27]$} \\
\hline Production & -0.1 & 0.0 & -0.0 & $-0.1^{* *}$ \\
\hline Rain & Yes & Yes & Yes & Yes \\
\hline Credit & Yes & Yes & Yes & Yes \\
\hline Inflation & Yes & Yes & Yes & Yes \\
\hline Observations & 7,269 & 7,886 & 7,912 & 8,828 \\
\hline Number of Accounts & 2,598 & 2,590 & 2,452 & 2,754 \\
\hline R & 0.14 & 0.17 & 0.17 & 0.17 \\
\hline
\end{tabular}




\section{Table 7A: Comparison between full-waiver and partial-waiver groups: Days outstanding pre and post waiver}

The table reports the regression results of the following equation for our sample of farmers in 4 districts of Andhra Pradesh, India, during 2005-2011:

Days $_{i t}=\alpha+v_{b}+\delta_{1}$ Post0 $+\delta_{2}$ Partialwaiver $\delta_{3}$ Post0 $^{*}$ Partial waiver $+B_{1}$ Loan $_{i t}+B_{1}$ Land $_{i t}+$ $B_{3}$ Production $_{d t}+B_{4}$ Rain $_{d t}+B_{5}$ Credit $_{d t}+B_{6}$ Inflation $_{t}+\varepsilon_{i t}$

The dependent variable Days $_{i t}$ is the number days the a loan is outstanding as on February 29, $2008(\mathrm{t}=$ 0 ) and February 28, $2011(\mathrm{t}=1)$ for farmer $i$. The independent variable, Post08, takes value 1 if the loan was taken in the post-waiver period; 0 otherwise. Partialwaiver takes a value of 1 if the farmer belongs to the partial-waiver group; 0 otherwise. Loan $_{i j t}$ represents the amount of loan $\mathrm{j}$ taken by farmer $\mathrm{i}$ in the pre-waiver period $(t=0)$ and in the post-waiver period $(t=1)$. Land ${ }_{i t}$ represents the landholding of farmer $\mathrm{i}$ in the two periods. Production ${ }_{d t}$ Rain $_{d t}$ and Credit $_{d t}$ are district-specific control variables and refer to the district $d$ that farmer i resides in. They represent the total food grains production, rainfall, and credit flow in the district in the year loan $\mathrm{j}$ is taken. Inflation $_{t}$ indicates inflation rates based on monthly consumer price index for agricultural laborers (CPIAL) in the pre-waiver period $(t=0)$ and in the post-waiver period $(t=1)$. Branch fixed effects $v_{b}$ are included in all specifications, and standard errors are cluster-adjusted at the branch level. T-statistics are reported in brackets.

Column 1 compares all loans before waiver with all loans after waiver. Column 2 compares the last loan before waiver with all loans after waiver. Column 3 compares the last loan before waiver with the first loan after waiver. Column 4 compares the last loan before waiver with the last loan after waiver in our sample period. T-statics are reported in brackets.

\begin{tabular}{|l|c|c|c|c|}
\hline & 1 & 2 & 3 & 4 \\
\hline VARIABLES & Days & Days & Days & Days \\
\hline Post08 & & & & -70.0 \\
\hline & $128.3^{* *}$ & 85.8 & $85.2 * *$ & {$[-1.1]$} \\
\hline Partialwaiver & {$[2.0]$} & {$[1.1]$} & {$[2.2]$} & -11.3 \\
\hline & 10.4 & 21.9 & -9.5 & {$[-1.3]$} \\
\hline Partialwaiver*Post08 & {$[0.4]$} & {$[0.8]$} & {$[-1.1]$} & $74.6^{* *}$ \\
\hline & -8.2 & -16.9 & 42.7 & {$[2.5]$} \\
\hline Loan & {$[-0.2]$} & {$[-0.4]$} & {$[1.2]$} & 0.0 \\
\hline & -0.0 & -0.0 & -0.0 & {$[1.1]$} \\
\hline Land & {$[-0.69]$} & {$[-0.83]$} & {$[-0.69]$} & $-0.1^{* * *}$ \\
\hline & 0.0 & $0.0 * * *$ & 0.0 & {$[-3.3]$} \\
\hline Production & {$[0.3]$} & {$[3.9]$} & {$[1.1]$} & $-0.3^{* * *}$ \\
\hline & -0.1 & -0.2 & $-0.4^{* * *}$ & {$[-6.0]$} \\
\hline Rain & {$[-1.6]$} & {$[-1.5]$} & {$[-6.9]$} & Yes \\
\hline Credit & Yes & Yes & Yes & Yes \\
\hline Inflation & Yes & Yes & Yes & Yes \\
\hline Brnach FE & Yes & Yes & Yes & Yes \\
\hline Observations & Yes & Yes & Yes & 9,999 \\
\hline Number of accno & 18,576 & 16,431 & 12,109 & 6,157 \\
\hline R & 7,057 & 7,057 & 7,057 & 0.37 \\
\hline
\end{tabular}


Table 7B: Comparison between full and partial-waiver groups with similar landholdings:

\section{Days outstanding in pre- and post-waiver periods (based on all loans pre and post waiver)}

The table reports the regression results of the following equation for our sample of farmers in 4 districts of Andhra Pradesh, India, during 2005-2011

Days $_{i t}==\alpha+v_{b}+\delta_{1}$ Post08 $+\delta_{2}$ Partialwaiver $\delta_{3}$ Post08 $^{*}$ Partialwaiver $+B_{1}$ Loan $_{i t}+B_{2}$ Production $_{d t}+$ $B_{3}$ Credit $_{d t}+B_{4}$ Rain $_{d t}+B_{5}$ Inflation $_{t}+\varepsilon_{i t}$

The dependent variable Days $s_{i t}$ is the number days the a loan is outstanding as on February 29, $2008(\mathrm{t}=$ 0 ) and February 28, 2011 ( $\mathrm{t}=1$ ) for farmer $i$. The independent variable, Post08, takes value 1 if the loan was taken in the post-waiver period; 0 otherwise. Partialwaiver takes a value of 1 if the farmer belongs to the partial-waiver group; 0 otherwise. Loan $_{i j t}$ represents the amount of loan $\mathrm{j}$ taken by farmer $\mathrm{i}$ in the pre-waiver period $(t=0)$ and in the post-waiver period $(t=1)$. Land ${ }_{i t}$ represents the landholding of farmer $\mathrm{i}$ in the two periods. Production ${ }_{d t}$ Rain $_{d t}$ and Credit ${ }_{d t}$ are district-specific control variables and refer to the district $d$ that farmer i resides in. They represent the total food grains production, rainfall, and credit flow in the district in the year loan $\mathrm{j}$ is taken. Inflation ${ }_{t}$ indicates inflation rates based on monthly consumer price index for agricultural laborers (CPIAL) in the pre-waiver period $(t=0)$ and in the post-waiver period $(t=1)$. Branch fixed effects $v_{b}$ are included in all specifications, and standard errors are cluster-adjusted at the branch level. T-statistics are reported in brackets.

Columns 1, 2, and 3 report results for the following three groups:

Group 1: 387 full-waiver and 404 partial-waiver farmers with landholdings in 1.8 - 2.2 hectares range Group 2: 392 full-waver and 427 partial-waiver farmers with landholdings in $1.75-2.25$ hectares range Group 3: 429 full-waiver and 443 partial-waiver farmers with landholdings in $1.7-2.3$ hectares range

\begin{tabular}{|l|c|c|c|}
\hline & $1.8-2.2$ & $1.75-2.25$ & $1.7-2.3$ \\
\hline & $(1)$ & $(2)$ & $(3)$ \\
\hline VARIABLES & Days & Days & Days \\
\hline Post08 & & & 107.2 \\
\hline & 81.6 & 90.8 & {$[1.4]$} \\
\hline Partialwaiver & {$[1.2]$} & {$[1.3]$} & -6.5 \\
\hline & -17.0 & -12.8 & {$[-0.2]$} \\
\hline Partialwaiver*Post08 & {$[-0.5]$} & {$[-0.4]$} & 32.2 \\
\hline & 50.8 & 43.0 & {$[0.7]$} \\
\hline Loan & {$[1.0]$} & {$[0.9]$} & 0.0 \\
\hline & 0.0 & 0.0 & {$[0.37]$} \\
\hline Production & {$[0.21]$} & {$[0.21]$} & -0.0 \\
\hline & -0.1 & -0.1 & {$[-0.9]$} \\
\hline Rain & {$[-1.6]$} & {$[-1.4]$} & Yes \\
\hline Credit & Yes & Yes & Yes \\
\hline Inflation & Yes & Yes & Yes \\
\hline Branch FE & Yes & Yes & Yes \\
\hline Observations & Yes & Yes & 2,461 \\
\hline No. of accounts: Full/Partial/Total & 2,257 & 2,321 & $429 / 443 / 872$ \\
\hline R $^{2}$ & $387 / 404 / 791$ & $392 / 427 / 819$ & 0.09 \\
\hline
\end{tabular}


Table 8A: Between group comparison:

New loan rejection rate in the post-waiver period

Column 1 of the table reports the PROBIT regression results of the following equation for our sample of farmers in 4 districts of Andhra Pradesh, India, during 2005-2011:

Reject $_{i}=\alpha+v_{b}+\delta_{1}$ fullwaiver $+\delta_{2}$ Partialwaiver $+\varepsilon_{i t}$,

where the dependent variable Reject $_{i}$ is a dummy which takes value 1 if the farmer $i$ does not have a loan after 29 February, 2008; 0 if he does. The independent variable Fullwaiver (Partialwaiver) takes value 1 if the farmer belongs to the full-waiver (partial-waiver) group; 0 otherwise.

Column 2 of the table reports the PROBIT regression results of the following equation for our sample:

Reject $_{i}=\alpha+v_{b}+\delta_{1}$ Default $+\varepsilon_{i t}$,

where the independent variable Default takes value 1 if the farmer belongs to either the full-waiver or the partial-waiver) group; 0 otherwise.

Branch fixed effects $v_{b}$ are included in all specifications. The standard errors are cluster-adjusted at the branch level. T-statistics are reported in brackets.

\begin{tabular}{|l|c|c|}
\hline & 1 & 2 \\
\hline VARIABLES & Reject & Reject \\
\hline & & \\
\hline Full waiver & $0.5^{* * *}$ & \\
\hline & {$[2.8]$} & \\
\hline Partial waiver & $1.0^{* * *}$ & \\
\hline & {$[4.4]$} & $0.7^{* * *}$ \\
\hline Default & & {$[4.3]$} \\
\hline & & Yes \\
\hline Branch FE & Yes & 12,612 \\
\hline Observations & 12,612 & 0.09 \\
\hline Pseudo R & 0.12 & \\
\hline
\end{tabular}




\section{Table 8B: Comparison between full and partial-waiver farmers: New loan rejection rate in the post-waiver period}

The table reports the PROBIT regression results of the following equation for our sample of farmers in 4 districts of Andhra Pradesh, India, during 2005-2011:

Reject $_{i}=\alpha+v_{b}+$ SPartialwaiver $+B_{1}$ Days $_{i}+B_{2}$ Land $_{i}+\varepsilon_{i t}$

The dependent variable Reject $_{\mathrm{i}}$ is a dummy reject which takes value 1 if the farmer $i$ does not have a loan after 29 February, 2008. The independent variable Partialwaiver takes value 1 if the farmer belongs to the partial-waiver group, otherwise 0. Days $s_{i}$ represents the number of days the number of days the loan of farmer $i$ in the pre-waiver period was outstanding. Land $_{i}$ is a control variable. It indicates the landholding of farmer $i$. Branch fixed effects $v_{b}$ are included in all specifications. The standard errors are cluster-adjusted at the branch level. T-statistics are reported in brackets.

\begin{tabular}{|l|c|c|c|}
\hline & $(1)$ & $(2)$ & $(3)$ \\
\hline VARIABLES & Reject & Reject & Reject \\
\hline & & & \\
\hline Partial waiver & $0.546^{* *}$ & $0.529^{* *}$ & $0.533^{* *}$ \\
\hline & {$[2.150]$} & {$[2.286]$} & {$[2.310]$} \\
\hline Days & $0.001^{* * *}$ & 0.000 & $-0.001^{* * *}$ \\
\hline & {$[2.881]$} & {$[0.666]$} & {$[-5.350]$} \\
\hline Days^2 & & -0.002 & -0.002 \\
\hline Land & & {$[-1.541]$} & {$[-1.531]$} \\
\hline & & & $0.000^{* * *}$ \\
\hline Branch FE & Yes & Yes & {$[3.933]$} \\
\hline Observations & 10,362 & 5,545 & Yes \\
\hline Pseudo $R^{2}$ & 0.23 & 0.25 & 5,545 \\
\hline
\end{tabular}




\section{Table 9: Within group comparison:}

\section{Average loan amount pre and post-waiver}

The table reports the regression results of the following equation for our sample of farmers in 4 districts of Andhra Pradesh, India, during 2005-2011:

loanamt $_{i t}=\alpha+v_{b}+\delta$ Post08 $+B_{1}$ Production $_{d t}+b_{2}$ rain $_{d t}+B_{3}$ Credit $_{d t}+B_{4}$ Inflation $_{d t}+\varepsilon_{i t}$

The dependent variable is the average loan amount taken by farmer $\mathrm{i}$ in the pre-waiver period $(\mathrm{t}=0)$ and the post-waiver period $(t=1)$. The independent variable of interest, Post08, takes value 1 if the loan is taken in the post-waiver period. Production ${ }_{d t}$ Rain $_{d t}$ and Credit $_{d t}$ are district-specific control variables and refer to the district $d$ that farmer $i$ resides in. They represent the total food grains production, rainfall, and credit flow in the district in the year loan $\mathrm{j}$ is taken. Inflation ${ }_{t}$ indicates inflation rates based on monthly consumer price index for agricultural laborers (CPIAL) in the pre-waiver period $(t=0)$ and in the post-waiver period $(t=1)$. Branch fixed effects $v_{b}$ are included in all specifications, and standard errors are cluster-adjusted at the branch level. T-statistics are reported in brackets.

The results for full-waiver farmers are in column 1, partial waiver farmers in column 2 and no-waiver farmers in column 3.

\begin{tabular}{|l|c|c|c|}
\hline & Full-waiver & Partial-waiver & No-waiver \\
\hline & $(1)$ & $(2)$ & $(3)$ \\
\hline VARIABLES & Loan & Loan & Loan \\
\hline & & & \\
\hline Post08 & $2,673.0$ & 614.5 & $-10,907.3$ \\
\hline & {$[1.5]$} & {$[0.1]$} & {$[-1.3]$} \\
\hline & & & \\
\hline Production & Yes & Yes & Yes \\
\hline Rain & Yes & Yes & Yes \\
\hline Credit & Yes & Yes & Yes \\
\hline Inflation & Yes & Yes & Yes \\
\hline Branch FE & Yes & Yes & Yes \\
\hline Observations & 20,748 & 5,662 & 8,845 \\
\hline$R^{2}$ & 0.11 & 0.09 & 0.12 \\
\hline
\end{tabular}

